\title{
Morphological, physiological and dietary covariation in migratory and resident adult brown trout ( Salmo trutta )
}

Peiman, Kathryn S.; Birnie-Gauvin, Kim; Larsen, Martin Hage; Colborne, Scott F.; Gilmour, Kathleen M.; Aarestrup, Kim; Willmore, William G; Cooke, Steven J.

\section{Published in:}

Zoology

Link to article, DOI:

10.1016/j.zool.2017.07.002

Publication date:

2017

Document Version

Peer reviewed version

Link back to DTU Orbit

Citation (APA):

Peiman, K. S., Birnie-Gauvin, K., Larsen, M. H., Colborne, S. F., Gilmour, K. M., Aarestrup, K., Willmore, W. G., \& Cooke, S. J. (2017). Morphological, physiological and dietary covariation in migratory and resident adult brown trout ( Salmo trutta ). Zoology, 123, 79-90. https://doi.org/10.1016/j.zool.2017.07.002

\section{General rights}

Copyright and moral rights for the publications made accessible in the public portal are retained by the authors and/or other copyright owners and it is a condition of accessing publications that users recognise and abide by the legal requirements associated with these rights.

- Users may download and print one copy of any publication from the public portal for the purpose of private study or research.

- You may not further distribute the material or use it for any profit-making activity or commercial gain

- You may freely distribute the URL identifying the publication in the public portal 


\section{Accepted Manuscript}

Title: Morphological, physiological and dietary covariation in migratory and resident adult brown trout (Salmo trutta)

Authors: Kathryn S. Peiman, Kim Birnie-Gauvin, Martin H. Larsen, Scott F. Colborne, Kathleen M. Gilmour, Kim Aarestrup, William G. Willmore, Steven J. Cooke

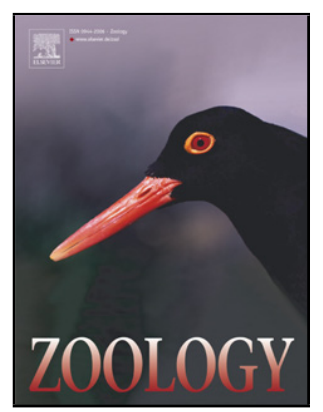

PII: S0944-2006(17)30006-5

DOI: http://dx.doi.org/doi:10.1016/j.zool.2017.07.002

Reference: ZOOL 25587

To appear in:

Received date: $\quad 12-1-2017$

Revised date: 6-7-2017

Accepted date: $\quad$ 6-7-2017

Please cite this article as: Peiman, Kathryn S., Birnie-Gauvin, Kim, Larsen, Martin H., Colborne, Scott F., Gilmour, Kathleen M., Aarestrup, Kim, Willmore, William G., Cooke, Steven J., Morphological, physiological and dietary covariation in migratory and resident adult brown trout (Salmo trutta).Zoology http://dx.doi.org/10.1016/j.zool.2017.07.002

This is a PDF file of an unedited manuscript that has been accepted for publication. As a service to our customers we are providing this early version of the manuscript. The manuscript will undergo copyediting, typesetting, and review of the resulting proof before it is published in its final form. Please note that during the production process errors may be discovered which could affect the content, and all legal disclaimers that apply to the journal pertain. 
Morphological, physiological and dietary covariation in migratory and resident adult brown trout (Salmo trutta)

Kathryn S. Peiman ${ }^{\mathrm{a}, *}$, Kim Birnie-Gauvin ${ }^{\mathrm{a}, \mathrm{b}, \mathrm{c}}$, Martin H. Larsen ${ }^{\mathrm{c}, \mathrm{d}}$, Scott F. Colborne ${ }^{\mathrm{e}}$, Kathleen M. Gilmour ${ }^{\mathrm{f}}$, Kim Aarestrup ${ }^{\mathrm{c}}$, William G. Willmore ${ }^{\mathrm{b}}$, Steven J. Cooke ${ }^{\mathrm{a}}$

${ }^{a}$ Fish Ecology and Conservation Physiology Laboratory, Department of Biology and Institute of Environmental Science, Carleton University, Ottawa, ON, Canada

b Department of Biology and Institute of Biochemistry, Carleton University, Ottawa, ON, Canada

c DTU AQUA, National Institute of Aquatic Resources, Section for Freshwater Fisheries Ecology, Technical University of Denmark, Silkeborg, Denmark

${ }^{\mathrm{d}}$ Danish Centre for Wild Salmon, Randers, Denmark

e Great Lakes Institute for Environmental Research, University of Windsor, Windsor, ON, Canada

${ }^{\mathrm{f}}$ Department of Biology, University of Ottawa, Ottawa, ON, Canada

* Corresponding author.

E-mail address: kathryn.peiman@ carleton.ca

\section{Highlights}

- Trait relationships may change depending on ecological conditions.

- Patterns of trait covariation differed between life-history strategies and sexes.

- The relationships among traits are subjected to different selection pressures. 


\begin{abstract}
The causes and consequences of trait relationships within and among the categories of physiology, morphology, and life-history remain poorly studied. Few studies cross the boundaries of these categories, and recent reviews have pointed out not only the dearth of evidence for among-category correlations but that trait relationships may change depending on the ecological conditions a population faces. We examined changes in mean values and correlations between traits in a partially migrant population of brown trout when migrant sea-run and resident stream forms were breeding sympatrically. Within each sex and life-history strategy group, we used carbon and nitrogen stable isotopes to assess trophic level and habitat use; assessed morphology which reflects swimming and foraging ability; measured circulating cortisol as it is released in response to stressors and is involved in the transition from salt to freshwater; and determined oxidative status by measuring oxidative stress and antioxidants. We found that sea-run trout were larger and had higher values of stable isotopes, cortisol and oxidative stress compared to residents. Most groups showed some correlations between morphology and diet, indicating individual resource specialization was occurring, and we found consistent correlations between morphology and cortisol. Additionally, relationships differed between the sexes (cortisol and oxidative status were related in females but not males) and between life-history strategies (habitat use was related to oxidative status in male sea-run trout but not in either sex of residents). The differing patterns of covariation between the two lifehistory strategies and between the sexes suggest that the relationships among phenotypic traits are subjected to different selection pressures, illustrating the importance of integrating multiple phenotypic measures across different trait categories and contrasting life-history strategies.
\end{abstract}

Keywords: Cortisol; Life-history strategy; Oxidative stress; Partial migration; Individual specialization

\title{
1. Introduction
}

Intraspecific competition can drive divergence among individuals within a species and result in resource polymorphisms and individual specialization, both of which are common though understudied processes in a variety of taxa (Skúlason and Smith, 1995; Smith and Skúlason, 1996; Martin and Pfennig, 2010; Dall et al., 2012). A resource polymorphism is defined as differences in habitat and/or resource use not due to sex or age that results in discrete 
phenotypic differences (Smith and Skúlason, 1996; Bolnick et al., 2003), while individual resource specialization occurs when an individual's niche width is small compared to the whole population (Bolnick et al., 2003). In fishes, resource-mediated divergence most frequently occurs along the littoral/inshore and limnetic/pelagic/offshore habitat axis (Robinson and Wilson, 1994). Polymorphisms and specialization can have important ecological and evolutionary consequences, including the potential to facilitate sympatric speciation (Smith and Skúlason, 1996; Dieckmann and Doebeli, 1999; Doebeli and Dieckmann, 2000; Jonsson and Jonsson, 2001; Bolnick and Fitzpatrick, 2007; Svanback and Persson, 2004).

Stable isotopes are one of the most common methods for identifying resource polymorphisms and individual specialization across taxa (e.g., Adams et al., 2003; McCarthy et al., 2004; Karpestam and Forsman, 2011) because they can be used to infer an individual's habitat and resource use (Kelly, 2000). In aquatic systems, diadromous individuals can be distinguished from residents because the marine environment has an enriched $\delta^{13} \mathrm{C}$ isotopic composition compared to freshwater systems (Hobson, 1999). Within each environment, littoral/inshore habitats have a more enriched $\delta^{13} \mathrm{C}$ isotopic composition than pelagic/offshore habitats (Hobson et al., 1994; France, 1995a; Kelly, 2000; Rubenstein and Hobson, 2004). Additionally, nitrogen isotopes become predictably enriched up the food chain due to the diettissue discrimination factors that occur between each trophic level (Kelly, 2000). Thus, $\delta^{13} \mathrm{C}$ values can be used as a proxy for habitat use, $\delta^{15} \mathrm{~N}$ values as a proxy for position within the food web (i.e., trophic level), and combined they provide a measure of space and food use during the period in which the sampled tissue was growing.

In species that exhibit partial migration, where some individuals in a population migrate and others remain resident, the causes and consequences of this life-history trade-off are still debated (Chapman et al., 2011). Brown trout (Salmo trutta) is a partially migrant species, with extensive life-history variation within and among populations (Klemetsen et al., 2003). In most areas, juveniles hatch in freshwater tributaries in the spring and spend 1-3 years in their natal stream before either migrating to sea, or staying and assuming residency (Klemetsen et al., 2003; Cucherousset et al., 2005; Boel et al., 2014), although some populations migrate within freshwater between streams and lakes (Olsson and Greenberg, 2004). Adult sea-run trout return most years to breed sympatrically with stream-residents in their natal freshwater streams. A juvenile's decision to stay or migrate is strongly affected by individual condition (Cucherousset 
et al., 2005; Olsson et al., 2006; Wysujak et al., 2009) though maternal effects and genetic factors also play a role (Paez et al., 2011; Hughes et al., 2016; Van Leeuwen et al., 2016). Even within these life-history strategies there is enormous variation in habitat use and diet. Some searun trout stay in fjords close to the mouths of their natal rivers while others migrate several kilometers to the sea (del Villar-Guerra et al., 2014), and sea-run trout feed in both nearshore shallow and offshore pelagic zones while residents can feed in littoral and pelagic zones of lakes and rivers (Jonsson and Gravem, 1985; Rikardsen and Amundsen, 2005). Adult brown trout consume the spectrum of available resources from benthic invertebrates and zooplankton to fish (Sanchez-Hernandez et al., 2012; Jensen et al., 2017). This variation has been linked to metrics such as body condition and length/age, but whether it also represents a resource polymorphism, individual specialization, or is related to other phenotypic traits, remains unknown.

There are few studies that integrate multiple phenotypic measures, especially across different trait categories and contrasting life-history strategies (Killen et al., 2013; Speakman et al., 2015; Peiman and Robinson, 2017). Trade-offs between life-history traits are well known, and these interrelationships mean that traits cannot be viewed independently (Stearns, 1989), but few studies have investigated whether trait relationships differ between divergent life-history strategies within a single species (Zera and Harshman, 2001). Here we use a population of brown trout exhibiting partial migration (sea-run versus stream-resident) to evaluate whether sex and life-history status affects mean trait values or relationships among four phenotypic traits. Specifically, we used isotopes to assess both trophic level and habitat use (Kelly, 2000); assessed morphology which reflects swimming and foraging ability (Blake, 2004); measured circulating cortisol concentrates, where cortisol is a steroid hormone that increases in concentration in response to stressors and is involved in the transition from salt to freshwater (McCormick, 2001; Barton, 2002); and determined oxidative status by measuring oxidative stress (the oxidation of thiols in glutathione) and the availability of antioxidants (Costantini and Verhulst, 2009). Using what is known about the hypothesized relationships among these phenotypic traits we made the following (numbered) hypotheses and predictions: (1) If morphology affects performance, more slender trout will have carbon isotope $\left(\delta^{13} \mathrm{C}\right)$ values indicative of offshore/pelagic feeding, while trout with a more piscivorous head shape will have nitrogen isotope $\left(\delta^{15} \mathrm{~N}\right)$ values indicative of feeding at higher trophic levels (i.e. incorporating fish into their diet). The first relationship should be present in sea-run trout as they have greater opportunity to forage in more distinctly 
offshore habitats, while the second should be present in all trout and independent of size and sex. (2) Morphology may be related to oxidative stress through its effects on performance (Vitousek et al., 2016). However, it is difficult to predict which aspects of morphology should be linked to oxidative stress, as previous research has focused on signal traits (such as used in mate attraction) and not on foraging or swimming morphology (Costantini, 2014). (3) Similarly, while glucocorticoids can affect morphology (Glennemeier and Denver, 2002; Butler et al., 2010; Hossie et al., 2010), there are no a priori predictions about which aspects of morphology will be affected by cortisol. (4) Oxidative stress may be affected by dietary quality and location (Beaulieu et al., 2015). If food at higher trophic levels contains antioxidants, nitrogen isotopes will be positively correlated with antioxidants and negatively correlated with oxidative stress. If increased foraging distance increases energy consumption and thus oxidative stress, carbon will be positively correlated with antioxidants and negatively correlated with oxidative stress, and this relationship should be stronger in migratory sea-run trout because they forage farther from shore than residents. (5) Similarly, the production of glucocorticoids may be stimulated when diet quality is low and located further away (Fairhurst et al., 2015), predicting a negative relationship between cortisol and both nitrogen and carbon isotopes, though again the relationship with carbon should be stronger in migrating sea-run trout feeding farther from shore. (6) Cortisol is also involved in the transition from salt to freshwater (McCormick and Bradshaw, 2006), and prolonged high cortisol levels can lead to oxidative stress (Costantini et al., 2011). As only sea-run trout make this transition, we predict sea-run trout will show a positive correlation between cortisol and oxidative stress, while residents will not.

\section{Materials and methods}

We concurrently caught adult resident and sea-run brown trout (Salmo trutta) by electrofishing on Oct 26-30, 2015 in the Kastbjerg River, Denmark (Fig 1). This implies that resident and sea-trout were breeding sympatrically in time and space (Olofsson and Mosegaard, 1999; Jonsson, 1985; Pettersson et al., 2001; Charles et al., 2004), though residents were more common upstream and sea-run trout more common downstream (Bagliniere et al., 1989; Charles et al., 2004). All males expressed milt upon gentle pressure, and females were identified based on abdominal dilatation (Monet et al., 2006). As all females did not have ripe eggs upon capture, there is likely variation in how long females took to spawn after sampling. 
Within 3 min of being shocked, a $0.3 \mathrm{ml}$ baseline blood sample (Pankurst, 2011) was withdrawn by caudal puncture using a 1.5-inch 25-gauge needle into a syringe coated with heparin. Fish were then tagged with a $23 \mathrm{~mm}$ passive integrated transponder (PIT) tag for individual identification (RI-TRP-RRHP, $134 \mathrm{~Hz}, 0.6 \mathrm{~g}$ mass in air, <1\% of fish weight; Texas Instruments, Plano, TX, USA). The electroshocking, air exposure during bleeding, and PIT tagging represented a stressor lasting approximately $4 \mathrm{~min}$. Trout were then held in 601 bins of stream water. After 30 min a second blood sample representing stress-induced cortisol levels was collected and treated as above. Within $10 \mathrm{~min}$ of collection, blood was centrifuged at $2000 \mathrm{~g}$ for 2 min, after which plasma was separated from red blood cells (RBCs). RBCs were flash-frozen in liquid nitrogen while plasma was kept on ice for less than $8 \mathrm{~h}$ and then transferred to a $-80{ }^{\circ} \mathrm{C}$ freezer. We then anesthetized trout using benzocaine $\left(0.03 \mathrm{~g} \mathrm{l}^{-1}\right)$, took a photograph, weighed each fish, and collected 5-10 scales from one side above the lateral line and below the dorsal fin. Individuals were sexed in the field (males released milt) and were classified as resident vs. sea trout based on $\delta^{13} \mathrm{C}$ values of scale samples (McCarthy and Waldron, 2000; Briers et al., 2013).

All applicable institutional and/or national guidelines for the care and use of animals were followed. Methods were approved by the Danish Technical University (license number 2012-DY-2934-00007) and the Canadian Council for Animal Care (administered by Carleton University - B14-06).

\subsection{Measurements of stable isotopes in scales}

We used scales as a non-lethal, time-integrated measure of diet and habitat use. Scales grow both outwardly and by underplating, and thus whole-scale isotope values are heavily biased by the last few months of feeding (Hutchingson and Trueman, 2006). Therefore, scales of individuals sampled in late October should be biased by their summer diet from approximately June onwards, i.e. for sea-run trout, marine feeding. Even though sea-run trout (especially males) reduce feeding and sometimes consume freshwater prey during spawning, while residents continue to feed during spawning (Shirvell and Dungey, 1983; Elliott, 1997; Harris, 1971), recent dietary changes are predicted to have small if any effect on isotope values in scales.

Scales were cleaned using distilled water, oven-dried for $24 \mathrm{~h}$, cut into fine pieces and placed into tin capsules, and analyzed at the Trophic Ecology Lab at the Great Lakes Institute for Environmental Research (University of Windsor, Windsor, ON, Canada). The values of $\delta^{13} \mathrm{C}$ and 
$\delta^{15} \mathrm{~N}$ were determined simultaneously using a continuous flow isotope ratio mass spectrometer (ThermoScientific Continuous Flow IRMS) coupled to a Costech Elemental Analyzer. Stable isotope ratios (\%) were determined by measuring the difference between heavy and light isotope ratios for both carbon $\left(\delta^{13} \mathrm{C}-\mathrm{C}^{13}: \mathrm{C}^{12}\right)$ and nitrogen $\left(\delta^{15} \mathrm{~N}-\mathrm{N}^{15}: \mathrm{N}^{14}\right)$ from standard reference materials ( $\mathrm{R}_{\text {standard }}$ ) of Vienna Pee Dee Belemnite and atmospheric nitrogen, respectively. Isotope ratios were calculated based on:

$\delta \mathrm{X}=\left[\mathrm{R}_{\text {sample }} / \mathrm{R}_{\text {standard }}-1\right] \times 1000$

where $\delta \mathrm{X}$ represents the isotope of interest, $\mathrm{R}_{\text {sample }}$ the measured ratio of the sample, and $\mathrm{R}_{\text {standard }}$ the standard reference material.

\subsection{Assessment of morphology}

We took a picture of the right side of each anesthetized fish using a Nikon camera mounted on a tripod in the field. Images were landmarked using the software tpsDig2 v2.25 (Rohlf, 2015). We initially placed 24 homologous landmarks on each image (Fig. 2). We first extracted five meristic measures (fork length, eye-to-snout length, anal fin length, maxillary length and premaxillary length) and used four points $(2,23,24,10)$ to straighten each specimen using a quadratic relationship ('unbend' function in tpsUtil v1.74), then removed the associated landmarks (points 1, 11, 17, 19, 23, 24) prior to analysis of geometric morphometrics. We then used MorphoJ to calculate partial warp scores and generate a principal components analysis (PCA, the relative warp scores) of size-corrected shape variation within each sex of sea-run and resident trout separately. We used this approach because there are known differences in morphology due to migratory status and sex (Monet et al., 2006) and these differences may affect the ability of a PCA to capture relevant variation within each group. We next checked for allometry by regressing centroid size against each PC axis and assessed significance using a permutation test with 10,000 rounds in MorphoJ (Klingenberg, 2016). When this test showed significant allometry (male stream-resident PC2, $p=0.0031$; male sea-run PC2, $p=0.0009$; all other $p>0.11$ ) we used the residuals of that regression for subsequent analysis. We then visualized shape changes using deformation grids along the resultant PC axes using tpsRegr v1.43 (Adams et al., 2004). We also regressed four meristic measures against fork length to generate size-corrected residuals which were used in univariate analyses. 


\subsection{Analysis of plasma cortisol concentrations}

We analyzed plasma cortisol concentrations using a commercial radioimmunoassay (RIA) kit (cat. 07-221105; MP Biomedicals, Eschwege, Germany) with a Perkin Elmer 2470 Gamma Counter. This kit has been previously validated for use with fish plasma (Gamperl et al., 1994). All samples were run in a single assay and the intra-assay coefficient of variation was $9.8 \%$.

\subsection{Determination of oxidative indicators}

To assess antioxidant capacity, each RBC sample from a single fish was homogenized on ice in 1:5 lysis buffer (20 mM Tris- $\mathrm{HCl}, 137 \mathrm{mM} \mathrm{NaCl}, 1 \%$ NP-40, 10\% glycerol, 2 mM EDTA) using a handheld Tissue Master 125 (Omni International, Kennesaw, GA, USA). Lysates were centrifuged at 13,000 rpm for $5 \mathrm{~min}$ at $4{ }^{\circ} \mathrm{C}$ in a Hermle Labnet Z216MK (Mandel Scientific, Guelph, ON, Canada) and supernatants were stored at $-80{ }^{\circ} \mathrm{C}$ until the oxygen radical absorbance capacity assay was performed (as described in Wilson et al., 2012) using a Cytation 5 microplate reader (BioTek Instruments, Winooski, VT, USA) and black 96-well Costar microplates. Fluorescence was measured with an excitation wavelength of $485 \mathrm{~nm}$ and emission wavelength of $520 \mathrm{~nm}$, and Gen5 data analysis software (2.07.17, BioTek Instruments) was used to analyze the data.

Each reaction well contained $20 \mu \mathrm{l}$ of either sample, blank (75 mM potassium phosphate, pH 7.4), or standard (6-hydroxy-2,5,7,8-tetramethylchroman-2-carboxylic acid (Trolox); 0-400 $\mu \mathrm{M}$ ), and $3.82 \mu \mathrm{M}$ fluorescein in $75 \mathrm{mM}$ potassium phosphate ( $\mathrm{pH}$ 7.4). The plate was incubated at $37{ }^{\circ} \mathrm{C}$ for $20 \mathrm{~min}$ before rapidly adding the free radical generator, 2,2"-azobis (2amidinopropane) dihydrochloride, to a final concentration of $79.8 \mathrm{mM}$. The plate was placed immediately in the microplate reader and the fluorescence was read every $80 \mathrm{~s}$ for $90 \mathrm{~min}$. The area under the fluorescence decay curve was determined for the samples and Trolox standards to calculate the Trolox equivalency, commonly used as a benchmark for antioxidant capacity. The total protein content of samples was determined using the BioRad assay and final antioxidant capacity values are reported in Trolox equivalents (TE)/ $\mu \mathrm{g}$ total protein.

To assess oxidative stress, each RBC pellet was ground on ice in non-denaturing lysis buffer (20 mM Tris-HCl, $137 \mathrm{mM} \mathrm{NaCl}, 1 \%$ NP-40, 10\% glycerol, 2 mM EDTA and $100 \mathrm{mM}$ 
PMSF in isopropanol), and centrifuged at $18500 \mathrm{~g}$ for $10 \mathrm{~min}$ at $4{ }^{\circ} \mathrm{C}$ in a Hermle Labnet Z216MK. Supernatants were mixed in 1:5 5\% sulfosalicylic acid solution (bubbled with $\mathrm{N}_{2}$ gas). Sample lysates were centrifuged at $18500 \mathrm{~g}$ for $10 \mathrm{~min}$ at $4{ }^{\circ} \mathrm{C}$. Supernatants were used to assess total glutathione (TGSH), oxidized glutathione (GSSG) and reduced glutathione (GSH) levels. GSH is assessed indirectly by computing TGSH $=$ GSH +2 GSSG. Glutathione assays were performed using an Epoch microplate reader with Gen5 data analysis software (2.00.18, BioTek Instruments) and clear 96-well Costar microplates. Glutathione assays were performed by following the rate of reduction of 5,5'-dithiobis(2-nitrobenzoic acid) (DTNB) by GSH at $412 \mathrm{~nm}$ compared to a standard curve of GSH (Hermes-Lima and Storey, 1996).

To measure TGSH, the reaction media contained $20 \mu \mathrm{l}$ of sample, $5 \mathrm{IU} / \mathrm{ml}$ glutathione reductase, $0.5 \mathrm{M}$ potassium phosphate buffer $(\mathrm{pH}$ 7.0), $0.3 \mathrm{mM}$ nicotinamide adenine dinucleotide 2'-phosphate, and $60 \mathrm{mM}$ DTNB. The reduction reaction was read for $30 \mathrm{~min}$ at $412 \mathrm{~nm}$ and compared to a GSH standard curve (0-4 mM). To quantify only GSSG, $50 \mu \mathrm{l}$ of the initial supernatant and the GSSG standards $(0-0.53 \mu \mathrm{M})$ were treated with $44.7 \mathrm{mM} \mathrm{2}$ vinylpyridine and $227.27 \mathrm{mM} \mathrm{KPi}$ in a total volume of $110 \mu \mathrm{l}$ and allowed to incubate at room temperature for $90 \mathrm{~min}$ to derivatize the GSH. Once complete, GSSG was measured in the same manner as TGSH.

\subsection{Statistical analyses}

We used ANCOVAs to assess whether differences in mean values of isotopes, oxidative indicators, and cortisol levels were due to migratory status, sex and their interaction, with length as a covariate. In brown trout, length is correlated with age (Jonsson, 1985; Grey, 2001) and our sampled fish likely encompassed similar age ranges across groups (Jonsson, 1985, 1989; Alp et al., 2005) so this covariate accounts for both size and age. We used ANOVAs to assess whether differences in mean values of meristic measures of morphology (which were already corrected for body size) were due to migratory status, sex and their interaction. We used multivariate correlations to assess whether geometric morphology, stable isotopes, oxidative indicators, and cortisol levels were related within each grouping of sex and migratory status, and we used partial correlations to determine each trait's effect when the other traits were held constant. To improve normality, TE was square root transformed, mass, length, baseline cortisol, stress-induced 
cortisol were log transformed, and GSSG/GSH was transformed by log +1 prior to use in ANCOVAs. All analyses were conducted in JMP v12.1.0 (SAS Institute, Cary, NC, USA).

\section{Results}

We collected samples from 7 resident females, 28 resident males, 36 sea trout females, and 31 sea trout males. Thus, our power to detect correlations and mean differences with resident females is limited compared to the other groups. We were also unable to assess partial correlations in female residents, as the number of variables exceeded our sample size. Average values $\pm \mathrm{SE}$ plus minimum and maximum values for each variable within sex and migratory status groups are presented in Table 1.

\subsection{Stable isotopes}

The two life-history types had non-overlapping $\delta^{13} \mathrm{C}$ values and barely overlapping $\delta^{15} \mathrm{~N}$ values, confirming we could use $\delta^{13} \mathrm{C}$ values to identify sea-run versus stream-resident individuals (Table 1). Within life-history types, sexes did not differ in $\delta^{13} \mathrm{C}(p=0.30)$ or $\delta^{15} \mathrm{~N}(p$ $=0.88)$. Visual examination of the data led us to explore the effect of length on nitrogen isotope values for the two life-history types: sea-run trout showed a negative relationship, whereas resident trout showed no relationship (after the largest resident male was excluded) with no differences between the sexes (length $\times$ migratory status, $F_{7,91}=7.69, p=0.0067$ ).

\subsection{Meristic morphology}

Sea trout were heavier $\left(F_{1,98}=82.2, p<0.0001\right)$ and longer $\left(F_{1.98}=69.1, p<0.0001\right)$ than resident trout (mean $\pm \mathrm{SE}$ : sea trout mass $=741 \pm 54 \mathrm{~g}$, length $=40 \pm 1.1 \mathrm{~cm}$; resident mass $=$ $187.5 \pm 19.7 \mathrm{~g}$, length $=25.1 \pm 0.7 \mathrm{~cm})$. Females were heavier $\left(F_{1,98}=5.29, p=0.023\right)$ and longer $\left(F_{1,98}=6.37, p=0.013\right)$ than males regardless of migratory status (migratory status $\times$ sex, $p>0.15)$. For their size, males had longer lower premaxillaries $\left(F_{1,98}=21.16, p<0.0001\right)$, longer upper premaxillaries $\left(F_{1,98}=25.73, \mathrm{p}<0.0001\right)$, and greater eye-to-snout lengths $\left(F_{1,98}=\right.$ $21.71, p<0.0001)$ than females, while residents had longer anal fins $\left(F_{1,98}=7.37, p=0.0078\right)$ than sea trout.

\subsection{Plasma cortisol concentrations}


Residents had lower baseline $\left(F_{1,88}=13.79, p=0.0004\right)$ and stress-induced $\left(F_{1,86}=12.67, p=\right.$ 0.0006) plasma cortisol concentrations than sea trout, while sexes did not differ $(p>0.32)$. Female sea trout showed a tendency to have higher stress-induced cortisol levels than male sea trout and both sexes of residents (sex $\times$ migratory status: $F_{1,86}=3.65, p=0.059$ ).

\subsection{Oxidative indicators}

Antioxidant capacity (TE) was not affected by migratory status or sex $(p>0.22)$. Sea trout had higher values of oxidative stress (GSSG/GSH) than residents $\left(F_{1,95}=9.68, p=0.0025\right)$, and the sexes did not differ $(p>0.49)$.

\subsection{Relationships between variables}

For geometric morphology, we were interested in variation within each group and so did not compare whole-body shape differences between sexes or life-history strategies. We restricted our interpretation to the first two PC axes, which in all groups explained $>13 \%$ of the total shape variation (Table 2). We interpret PC1 as changes in head shape, with more positive values reflecting more piscivorous morphologies, and we interpret PC2 as body shape, with more positive values reflecting more fusiform morphologies (see Fig. S1 in the supplementary online Appendix).

(1) Head morphology (PC1) was positively related to diet $\left(\delta^{15} \mathrm{~N}\right)$ in male residents (multivariate correlation $p=0.020$; partial correlation $p=0.058$; Figs. 3a and 4). Head morphology (PC1) and body morphology (PC2) was positively related to diet $\left(\delta^{15} \mathrm{~N}\right)$ in female sea-run trout (PC1 multivariate correlation $p=0.051$, partial correlation $\mathrm{p}=0.061$; PC2 partial correlation $p=0.023$; Fig. $3 \mathrm{~d}$ ). There were no other relationships between geometric morphology (PC1 or 2) and isotope values (all $p>0.11$ ). Several meristic measures were related to diet in residents: lower premaxillary length was positively related to $\delta^{15} \mathrm{~N}$ in female residents $\left(r^{2}=\right.$ $0.70, p=0.019$; all other $p>0.12)$, and lower premaxillary length $\left(r^{2}=0.34, p=0.0011\right)$, upper premaxillary length $\left(r^{2}=0.41, p=0.0002\right)$ and eye-to-snout length $\left(r^{2}=0.30, p=\right.$ 0.0026 ) were all positively related to $\delta^{15} \mathrm{~N}$ in male residents (all other $p>0.59$ ). In male residents, meristic measures were also related to habitat use: lower premaxillary length $\left(r^{2}=\right.$ $0.25, p=0.0061)$, upper premaxillary length $\left(r^{2}=0.25, p=0.0064\right)$ and eye-to-snout length $\left(r^{2}=0.33, p=0.0013\right)$ were all positively related to $\delta^{13} \mathrm{C}$ (all other $\left.p>0.30\right)$. Anal fin length 
was positively related to $\delta^{13} \mathrm{C}$ in female sea trout $\left(r^{2}=0.12, p=0.036\right.$; all other $\left.p>0.48\right)$. No other meristic measure was related to $\delta^{15} \mathrm{~N}$ (all $p>0.084$ ) or $\delta^{13} \mathrm{C}$ (all $p>0.23$ ).

(2) No oxidative indicator was related to geometric morphology (all $p>0.075$ ).

(3) Stress-induced cortisol levels were negatively related to head morphology (PC1) in female sea-run trout (partial correlation $p=0.0041$; Figs. 3d and 5a) and female residents (multivariate correlation $p=0.040$; Figs. $3 \mathrm{~b}$ and $5 \mathrm{~b}$ ). Stress-induced cortisol levels were negatively related to body morphology (PC2) in male sea-run trout (multivariate correlation $p$ $=0.048$; partial correlation $p=0.052$; Figs. $3 \mathrm{c}$ and $5 \mathrm{c}$ ) and showed the same pattern with baseline cortisol in male residents (multivariate correlation $p=0.074$ ).

(4) Oxidative stress (GSSG/GSH) was positively related to $\delta^{13} \mathrm{C}$ in male sea-run trout (multivariate correlation $p=0.0016$; partial correlation $p=0.061$; Figs. $3 \mathrm{c}$ and 6). No other oxidative indicator was related to isotope values (all $p>0.17$ ).

(5) Stress-induced cortisol concentration was positively related to $\delta^{15} \mathrm{~N}$ in female sea-run trout (multivariate correlation $p=0.025$, partial correlation $p=0.045$; Figs. $3 \mathrm{~d}$ and 7). Baseline and stress-induced cortisol levels were positively related to $\delta^{13} \mathrm{C}$ in male residents (multivariate correlation $p=0.036$ and $p=0.049$, respectively; Figs. 3a and 7), while only stress-induced cortisol concentration was positively related to $\delta^{13} \mathrm{C}$ in male sea trout (multivariate correlation $p=0.0050$; Figs. $3 \mathrm{c}$ and 7). Cortisol was not related to stable isotopes in female residents (all $p>0.10$ ).

(6) Baseline cortisol concentration was positively related to oxidative stress (GSSG/GSH) and stress-induced cortisol concentration was positively related to antioxidant capacity (TE) in female residents (multivariate correlation $p=0.0080$ and $p=0.021$, respectively; Fig. 3b). Stress-induced cortisol level was positively related to oxidative stress (GSSG/GSH) in female sea trout (multivariate correlation $p=0.027$, partial correlation $p=0.051$; Fig. 3d) and baseline cortisol level was positively related to antioxidant capacity (TE; multivariate correlation $p=0.045$ ). No other measure of cortisol concentration was related to oxidative stress (all $p>0.081)$.

\section{Discussion}

The causes and consequences of trait relationships within and among the categories of physiology, morphology, and life-history remain poorly studied (Peiman and Robinson, 2017). 
Few studies cross the boundaries of these categories, and recent reviews have pointed out not only the dearth of evidence for among-category correlations but that trait relationships may change depending on the ecological conditions a population faces (Costantini et al., 2011; Killen et al., 2013; Beaulieu et al., 2015; Fairhurst et al., 2015; Speakman et al., 2015; Hau et al., 2016). New fields and conceptual frameworks linking physiology to ecology are emerging, such as 'oxidative ecology' (McGraw et al., 2010), the 'life-history physiology nexus' (Ricklefs and Wikelski, 2002) and 'pace-of-life' syndromes (Reale et al., 2010), which link the causes and consequences of variation on an individual's phenotype throughout their life (Metcalfe and Alonso-Alvarez, 2010). Here we contribute to the growing field of trait correlations among categories and investigate whether multiple aspects of averaged and integrated phenotypes have diverged between sexes and between a resident and migrant life-history strategy.

Trophic polymorphisms and individual specialization are important ecological and evolutionary processes that can reduce intraspecific competition (Van Valen, 1965; Roughgarden, 1972; Polis, 1984; Smith, 1990; Smith and Skúlason, 1996). They both attempt to attribute variation in diet to morphology that is not related to sex or age. The difference between these two processes is whether morphological variation is discrete or continuous, with resource polymorphisms strictly defined as requiring discrete morphotypes and individual specialization used when morphological variation is continuous (Bolnick et al., 2003). We did not find any evidence of discrete morphotypes (i.e., clear separation of morphology along any PC axis within sex and life-history strategies), and so interpret our results in terms of individual resource specialization. We do not have multiple measures of diet and thus no measure of individual niche width, and so could not conduct a formal analysis of specialization (Bolnick et al., 2003). However, the wide variation in nitrogen values we found using a time-integrated tissue suggests that individual specialization is occurring (Grey, 2001) and others have suggested that brown trout show individual specialization (Bridcut and Giller, 1995), though this variation could also be generated by dietary shifts (e.g., seasonal variation) that differ in magnitude among individuals. Brown trout are generally described as opportunistic feeders in both freshwater and marine habitats (Ringler, 1985; Elliott, 1997; Knutsen et al., 2001; Klemetsen et al., 2003; Knutsen et al., 2004; Rikardsen and Amundsen, 2005; Jensen et al., 2017) and so the potential exists for individual specialization within this wide population-level niche based on morphology. We found the predicted relationship in both sexes of residents and in female sea-run trout: 
individuals with a benthic head morphology (negative values of PC1 and/or shorter premaxillaries and a shorter eye-to-snout distance; Skoglund et al., 2015) had lower $\delta^{15} \mathrm{~N}$ values while individuals with a more piscivorous head morphology (positive values of PC1 and/or longer premaxillaries and a longer eye-to-snout distance) had higher $\delta^{15} \mathrm{~N}$ values. Nitrogen stable isotope values reflect stomach contents in fish (Vander Zanden et al., 2007; Jensen et al., 2012, 2017) and can capture individual resource specialization (Beaudoin et al., 1999). However, we do not know baseline isotope values or the actual diet of individuals in our study, and so we can only infer that individuals with lower $\delta^{15} \mathrm{~N}$ values consumed more invertebrates while those with higher $\delta^{15} \mathrm{~N}$ values consumed more fish. Regardless, this relationship was independent of both length (a proxy for age) and allometry, and so did not represent a simple ontogenetic diet shift or changes in morphology due to further maturation in older fish, i.e. effects of sex steroids. This supports the hypothesis that residents and female migratory trout exhibit dietary specialization, where differences in resource use are correlated with functional morphology (Bolnick et al., 2003; Svanback and Bolnick, 2007).

We also found that in sea-run trout of both sexes, larger individuals had lower $\delta^{15} \mathrm{~N}$ values, which seems to contradict the well-known pattern that trout consume higher trophic levels (i.e., become piscivorous) as they get larger (L’Abee-Lund et al., 1992; Grey, 2001; Jensen et al., 2012). Trout can show seasonal shifts in prey use (Knutsen et al., 2001; Rikardsen and Amundsen, 2005; Rikardsen et al., 2006), but for this to explain our observed pattern, the largest fish would have had to switch to consuming a trophic level below what the smallest fish consume (or the smallest fish switched to a higher trophic level than the largest fish) during the time of scale growth (summer), which has never been reported. Additionally, the wide variation in sea-run trout scale $\delta^{15} \mathrm{~N}$ values (range 12.7-20.1 for females and 15.1-19.4 for males, Table 1) suggests that females utilized four trophic levels while males used almost three levels (assuming an average trophic enrichment for nitrogen of 2.5 in fishes; Caut et al., 2009). It seems unlikely that the smallest trout would primarily consume predatory prey fish while the largest fish would primarily consume zooplankton. As previous studies found no relationship between length and nitrogen isotopes in sea-run trout (Acolas et al., 2008; Vuori et al., 2012), there is no clear explanation for our observed negative relationship.

In fishes, resource-mediated divergence most frequently occurs along the littoral/inshore and pelagic/offshore habitat axis (Robinson and Wilson, 1994). Fish in littoral habitats are 
predicted to have deeper bodies (Smith and Skúlason, 1995; Wilson, 1998), consume benthic prey (Smith and Skúlason, 1995; Rikardsen and Amundsen, 2005) and have more enriched carbon values (Hobson et al., 1994; France, 1995a; Kelly, 2000; Rubenstein and Hobson, 2004). Surprisingly, our measure of habitat use $\left(\delta^{13} \mathrm{C}\right.$ values) indicated that resident males with a more piscivorous head shape (longer meristic measures of premaxillary and eye-to-snout lengths) inhabited littoral habitats. However, as we also found that carbon and nitrogen values were positively correlated with each other, this suggests that the trophic enrichment of carbon isotope values in small stream systems may swamp habitat-specific differences (France, 1995b; Kelly, 2000). We did not expect that these effects of morphology on diet would be absent in male searun trout. Sea-run trout can show considerable variation in habitat use, with some individuals moving up to $50 \mathrm{~km}$ away from shore (Rikardsen and Amundsen, 2005), and long-distance sea migrants spend more time in pelagic habitats while short-distance migrants stay in the fjord, suggesting behavioral habitat matching (Eldoy et al., 2015). It may be that morphology more strongly affects competitive interactions for space or prey among individuals in the limited area of small streams rather than the open waters of fjords or the sea.

Sea trout had on average more oxidative stress than residents, even though antioxidant capacity did not differ, indicating they had more pro-oxidants (Costantini and Verhulst, 2009) that likely resulted in increased oxidative damage (Pisoschi and Pop, 2015). This effect may be a result of their recent migration to the spawning grounds, because high levels of exercise can cause an increase in the production of reactive oxygen species (Costantini, 2008). However, male sea-run trout from presumably closer inshore habitats (more enriched carbon values) had higher levels of oxidative stress (GSSG/GSH) than those from presumably offshore habitats, which is the opposite pattern to the prediction under the distance-energy consumption hypothesis. Similarly, in Adelie penguins (Pygoscelis adeliae) and Atlantic salmon (Salmo salar), oxidative stress was positively correlated with carbon isotope values (Beaulieu et al., 2010; Vuori et al., 2012). This location effect may be driven by contamination if inshore habitats have more pollutants than offshore habitats (Peters et al., 1994), by physiological constraints if poor quality individuals stay closer inshore (Beaulieu et al., 2010), by partial food deprivation if inshore habitats have a lower quantity of prey (Bayir et al., 2011), or by temperature if inshore habitats are warmer (Lesser, 2006). However, it is unclear why these possibilities would affect males and not females in our study, because the sexes did not differ in average carbon isotopes and thus 
presumably habitat use. Fasting can also cause oxidative damage (Bayir et al., 2011) and sea trout - especially males - have reduced food intake while spawning compared to residents (Elliott, 1997) and so this is another possible explanation for the higher oxidative stress in searun trout, though we found no sex effects on average oxidative stress values either. However, the relatively short duration and recent onset of fasting should not affect carbon isotope values in whole scales as they have very low lipid content, and so does not explain the relationship between long-term carbon isotope values and oxidative stress either. Oxidative stress is not clearly related to reproductive status or age (Selman et al., 2013; Wilson et al., 2012), and so also does not explain differences in life-history strategies. We also found no support for the prediction that trophic level (based on nitrogen stable isotope values) was related to oxidative status.

Prolonged high cortisol levels are another mechanism that can lead to oxidative stress (reviewed in Costantini et al., 2011). Here, females (both sea-run and resident) but not males showed a positive relationship between cortisol levels and oxidative stress. The relationship changed between females of the two life-history strategies: residents with higher baseline cortisol values had higher levels of oxidative stress, and higher stress-induced cortisol concentration was associated with higher antioxidant capacity, whereas in sea-run trout higher baseline cortisol level was associated with higher antioxidant capacity and higher stress-induced cortisol concentration was associated with higher oxidative stress. However, caution should be taken in interpreting the lack of reciprocal relationships in the resident females, because all associations were positive and likely lacked the statistical power to reach significance. Regardless, it is clear that females have a positive association between cortisol levels and oxidative stress while males do not. This general trend is supported by a meta-analysis that showed females were more susceptible to the effects of glucocorticoids on oxidative stress than males (Costantini et al., 2011) but contrasts with a study on female resident brown trout which found no relationship between oxidative stress and baseline cortisol concentrations (Hoogenboom et al., 2012). Clearly, our prediction that a relationship between cortisol levels and oxidative stress would be seen in sea-run trout only was not supported. Thus, different mechanisms may be more important in affecting oxidative stress in males (e.g., contaminants) versus females (e.g., cortisol).

While glucocorticoids can also affect morphology during development (Glennemeier and Denver, 2002; Butler et al., 2010; Hossie et al., 2010), there are no a priori predictions about 
which aspects of morphology should be affected especially when measured in mature fish. We found a negative relationship with stress-induced cortisol concentrations in all groups: in females, more piscivorous head shapes were related to lower cortisol, and in males, more fusiform bodies were related to lower cortisol. Thus, despite this type of relationship being absent from the literature, it turned out to be one of our most consistent results across groups. However, the causal direction and mechanism of this relationship remains unclear, and deserves further study.

Cortisol is also involved in the physiological preparation for saltwater/freshwater transitions (McCormick, 2001), increasing in salmonids during smoltification to prepare smolts for entry into the marine environment (McCormick, 2001) as well as in mature fish preparing to enter the freshwater environment to spawn (Flores et al., 2012). Both baseline and stress-induced cortisol were elevated in sea-run compared to resident trout, in agreement with a role for cortisol in the seawater-to-freshwater transition, although in sympatric resident and migratory brook charr (Salvelinus fontinalis) no differences were found in cortisol levels (Boula et al., 2002). While the reduction in food intake that sea-run trout experience upon freshwater entry may also affect cortisol levels, empirical evidence that fasting affects cortisol is not strong (Sumpter et al., 1991; Pottinger et al., 2003; Azodi et al., 2015; but see Barcellos et al., 2010). Female sea trout also had higher cortisol values than female residents, and because cortisol levels increase as spawning approaches (reviewed in Hoogenboom et al., 2012), this observation suggests that searun trout may have been more advanced in their readiness to spawn than were residents.

The relationship between stable isotope values and cortisol levels has been studied almost exclusively within the avian literature, and most studies focused on averages rather than correlations between the two traits. The most comprehensive studies found a negative relationship between a time-integrated measure of corticosterone levels and both $\delta^{15} \mathrm{~N}$ (Fairhurst et al., 2015) and $\delta^{13} \mathrm{C}$ (Fairhurst et al., 2013) values, consistent with the general expectation that glucocorticoids are elevated when diet quality is low and feeding grounds are located further away (Fairhurst et al., 2015). Yet all the relationships that we found were positive, indicating that higher levels of both baseline and stress-induced cortisol were associated with higher trophic levels and inshore habitat use, and so our results do not support those predictions. The relationships we observed were also quite consistent across groups, arguing against spurious associations. One reason our results may differ from previous studies involves the time scale 
over which these traits were measured. The avian studies used feathers for both corticosterone and stable isotope measurements, so that glucocorticoids and diet reflect a time-integrated measure over the same period. We measured diet and cortisol at different time points (cortisol during autumn breeding, diet from summer onwards) and diet was integrated over a much longer time scale (months in scales versus weeks in feathers) while cortisol was an active hormone that could still respond to current events. Thus, our measured association more closely reflects a carry-over effect, where conditions in one part of the year (here summer feeding) affect traits during another part of the life cycle (here levels of stress hormones preceding breeding) (Harrison et al., 2011; O’Connor et al., 2014). This observation highlights the importance of matching the appropriate tissues and therefore time scales to the research question (Warne et al., 2015), and that trait relationships can change depending on the time scale over which they are measured.

Trait correlations have two distinct sources: causal linkages between traits (i.e., structural dependence or pleiotropy) and adaptive covariation (i.e., correlational selection) (Peiman and Robinson, 2017). While the absence of correlations suggests that single trait values are under selection, the presence of correlations in a single population does not distinguish between their potential sources. One method to distinguish sources is to measure the fitness of phenotypes with different trait combinations, but there have been few attempts to do this outside the behavioral syndrome literature. However, if the effects of fitness components (growth, reproduction, or survival) differ between sexes or life-history strategies, adaptive trait covariation is predicted to vary while causal linkages are not expected to be modified. For example, covariation between cortisol and oxidative status in females but not males indicates that reproduction may have the strongest effect on this relationship, while covariation between habitat use and oxidative status in male sea-run trout but not residents suggests that survival may modify this relationship. Additionally, consistent relationships between morphology and diet suggest that this functional relationship is important for maximizing growth in all groups, while the relationship between stress hormone levels and morphology may reflect a causal organizing effect. However, correlations can also be affected by age, individual quality, nutritional status, season, and environmental conditions (reviewed in Peiman and Robinson, 2017). Thus, while differing patterns of covariation between the two life-history strategies and the sexes suggest the intriguing possibility that the relationships among phenotypic traits are subjected to different 
selection pressures, this remains to be tested. This illustrates the importance of integrating multiple phenotypic measures across different trait categories and contrasting life-history strategies, and that a more holistic approach to trait covariation is warranted (Reale et al., 2010; Ballew et al., 2017). We know little about the causal mechanisms driving most trait relationships, and how the many differences between the two life-history types (e.g., degree of reproductive maturity, fasting during migration, competition) independently affect trait covariation. As brown trout show genetic structuring even at micro-geographic scales (Cawdery and Ferguson, 1988; Ferguson and Taggart, 1991; McVeigh et al., 1995; Estoup et al., 1998; Carlsson et al., 1999; Hansen et al., 2002; Duguid et al., 2006) and life-history strategies have a heritable component (Hughes et al., 2016), the maintenance of genetically based trait-linked variation is possible through the use of different breeding habitats or even isolation by distance along rivers. Promising future directions include studies on the fitness effects and determining the causal direction of these trait relationships.

\section{Acknowledgments}

The authors thank Jørgen Skole Mikkelsen and Morten Carøe for assistance in the field. This work was supported by a Natural Sciences and Engineering Research Council (NSERC) of Canada Discovery Grant (DG) and E.W.R. Steacie Memorial Fellowship to S.J. Cooke, the Canada Research Chairs Program, NSERC DG and Research Tools and Instruments Grant to K.M. Gilmour, NSERC DG and CREATE grants to W.B. Willmore, and the Danish Rod and Net Fish License Funds to the Technical University of Denmark.

\section{Appendix A. Supplementary data}

Supplementary data associated with this article can be found in the online version at doi: \#\#\#. 


\section{References}

Acolas, M.-L., Roussel, J.-M., Bagliniere, J.-L., 2008. Linking migratory patterns and diet to reproductive traits in female brown trout (Salmo trutta L.) by means of stable isotope analysis on ova. Ecol. Fresh. Fish 17, 382-393.

Adams, C., Fraser, D., McCarthy, I., Shields, S., Waldron, S., Alexander, G., 2003. Stable isotope analysis reveals ecological segregation in a bimodal size polymorphism in Arctic charr from Loch Tay, Scotland J. Fish Biol. 6, 474-481.

Adams, D.C., Rohlf, F.J., Slice, D.E., 2004. Geometric morphometrics: ten years of progress following the 'revolution'. Ital. J. Zool. 71, 5-16.

Alp, A., Kara, C., Buhukcapar, H.M., 2005. Age, growth and diet composition of the resident brown trout, Salmo trutta macrostigma Dumeril 1858, in Firniz stream of the River Ceyhan, Turkey. Turkish J. Vet. Anim. Sci. 29, 285-295.

Azodi, M., Ebrahimi, E., Motaghi, E., Morshedi, V., 2015. Metabolic responses to short starvation and re-feeding in rainbow trout (Oncorhynchus mykiss). Ichthyol. Res. 62, 177-183.

Bagliniere, J.L., Maisse, G., Lebail, P.Y., Nihouarn, A., 1989. Population dynamics of brown trout, Salmo trutta L., in a tributary in Brittany (France): spawning and juveniles. J. Fish Biol. 34, 97-110.

Ballew, N.G., Mittelbach, G.G., Scribner, K.T., 2017. Fitness consequences of boldness in juvenile and adult largemouth bass. Am. Nat. 189, 396-406.

Barcellos, L.J.G., Marqueze, A., Trapp, M., Quevedo, R.M., Ferreira, D., 2010. The effects of fasting on cortisol, blood glucose and liver and muscle glycogen in adult jundia Rhamdia quelen. Aquaculture 300, 231-236.

Barton, B.A., 2002. Stress in fishes: a diversity of responses with particular reference to changes in circulating corticosteroids. Integr. Comp. Biol. 42, 517-525.

Bayir, A., Sirkecioglu, A.N., Bayir, M., Haliloglu, H.I., Kocaman, E.M., Aras, N.M., 2011. Metabolic responses to prolonged starvation, food restriction, and refeeding in the brown trout, Salmo trutta: oxidative stress and antioxidant defenses. Comp. Biochem. Physiol. B 159, 191-196.

Beaudoin, C.P., Tonn, W.M., Prepas, E.E., Wassenaar, L.I., 1999. Individual specialization and trophic adaptability of northern pike (Esox lucius): an isotope and dietary analysis. Oecologia 120, 386-396. 
Beaulieu, M., Ropert-Coudert, Y., Le Maho, Y., Ancel, A., Criscuolo, F., 2010. Foraging in an oxidative environment: relationship between delta13C values and oxidative status in Adelie penguins. Proc. Biol. Sci. 277, 1087-1092.

Beaulieu, M., Gonzalez-Acuna, D., Thierry, A.-M., Polito, M.J., 2015. Relationships between isotopic values and oxidative status: insights from populations of gentoo penguins. Physiol. Ecol. 177, 1211-1220.

Blake, R.W., 2004. Fish functional design and swimming performance. J. Fish Biol. 65, 1193-1222.

Boel, M., Aarestrup, K., Baktoft, H., Larsen, T., Madsen, S.S., Malte, H., Skov, C., Svendsen, J.C., Koed, A., 2014. The physiological basis of the migration continuum in brown trout (Salmo trutta). Physiol. Biochem. Zool. 87, 334-345.

Bolnick, D.I., Fitzpatrick, B.M., 2007. Sympatric speciation: models and empirical evidence. Annu. Rev. Ecol. Evol. Syst. 38, 459-487.

Bolnick, D.I., Svanback, R., Fordyce, J.A., Yang, L.H., Davis, J.M., Hulsey, C.D., Forister, M.L., 2003. The ecology of individuals: incidence and implications of individual specialization. Am. Nat. 161, 1-28.

Boula, D., Castric, V., Bernatchez, L., Audet, C., 2002. Physiological, endocrine, and genetic bases of anadromy in the brook charr, Salvelinus fontinalis, of the Laval River (Quebec, Canada). Environ. Biol. Fishes 64, 229-242.

Bridcut, E.E., Giller, P.S., 1995. Diet variability and foraging strategies in brown trout (Salmo trutta): an analysis from subpopulations to individuals. Can. J. Fish. Aquat. Sci. 52, 2543-2552.

Briers, R.A., Waterman, J.O., Galt, K., Campbell, R.N.B., 2013. Population differentiation and temporal changes of carotenoid pigments and stable isotope ratios in the offspring of anadromous and non-anadromous trout Salmo trutta. Ecol. Freshw. Fish 22, 137144.

Butler, M.W., Leppert, L.L., Dufty Jr. A.M., 2010. Effects of small increases in corticosterone levels in morphology, immune function, and feather development. Physiol. Biochem. Zool. 83, 78-86.

Carlsson, J., Olsen, K.H., Nilsson, J., Overli, O., Stabell, O.B., 1999. Microsatellites reveal fine-scale genetic structure in stream-living brown trout. J. Fish Biol. 55, 1290-1303. 
Cawdery, S.A.H., Ferguson, A., 1988. Origins and differentiation of three sympatric species of trout (Salmo trutta L.) in Lough Melvin. Polskie Arch. Hydrobiol. 35, 267-277.

Chapman, B.B., Bronmark, C., Nilsson, J.-A., Hansson, L.-A., 2011. The ecology and evolution of partial migration. Oikos 120, 1764-1775.

Charles, K., Roussel, J.-M., Cunjak, R.A., 2004. Estimating the contribution of sympatric anadromous and freshwater resident brown trout to juvenile production. Marine Fresh. Res. 55, 185-191.

Costantini, D., 2008. Oxidative stress in ecology and evolution: lessons from avian studies. Ecol. Lett. 11, 1238-1251.

Costantini, D., 2014. Oxidative Stress and Hormesis in Evolutionary Ecology and Physiology: A Marriage Between Mechanistic and Evolutionary Approaches. Springer-Verlag, Berlin.

Costantini, D., Marasco, V., Moller, A.P., 2011. A meta-analysis of glucocorticoids as modulators of oxidative stress in vertebrates. J. Comp. Physiol. B 181, 447-456.

Cucherousset, J., Ombredane, D., Charles, K., Marchand, F., Bagliniere, J.-L., 2005. A continuum of life history tactics in a brown trout (Salmo trutta) population. Can. J. Fish. Aquat. Sci. 62, 1600-1610.

Dall, S.R.X., Bell, A.M., Bolnick, D.I., Ratnieks, F.L.W., 2012. An evolutionary ecology of individual differences. Ecol. Lett. 15, 1189-1198.

Davenport, S.R., Bax, N.J., 2002. A trophic study of a marine ecosystem off southeastern Australia using stable isotopes of carbon and nitrogen. Can. J. Fish. Aquat. Sci. 59, 514-530.

del Villar-Guerra, D., Aarestrup, K., Skov, C., Koed, A., 2014. Marine migrations in anadromous brown trout (Salmo trutta). Fjord residency as a possible alternative in the continuum of migration to the open sea. Ecol. Freshw. Fish 23, 594-603.

Dieckmann, U., Doebeli, M., 1999. On the origin of species by sympatric speciation. Nature 400, 354-357.

Doebeli, M., Dieckmann, U., 2000. Evolutionary branching and sympatric speciation caused by different types of ecological interactions. Am. Nat. 156, S77-S101.

Duguid, R.A., Ferguson, A., Prodohl, P., 2006. Reproductive isolation and genetic differentiation of ferox trout from sympatric brown trout in Loch Awe and Loch Loggan, Scotland. J. Fish Biol. 69, 89-114. 
Eldoy, S.H., Davidsen, J.G., Thorstad, E.B., Whoriskey, F., Aarestrup, K., Naesje, T.F., Ronning, L., Sjursen, A.D., Rikardsen, A.H., Arnekleiv, J.V., 2015. Marine migration and habitat use of anadromous brown trout (Salmo trutta). Can. J. Fish. Aquat. Sci. 72, 1366-1378.

Elliott, J.M., 1997. Stomach contents of adult sea trout caught in six English rivers. J. Fish Biol. 50, 1129-1132.

Estoup, A., Rousset, F., Michalakis, Y., Cornuet, J.-M., Adriamanga, M., Guyomard, R., 1998. Comparative analysis of microsatellite and allozyme markers: a case study investigating microgeographic differentiation in brown trout (Salmo trutta). Mol. Ecol. 7, 339-353.

Fairhurst, G.D., Vogeli, M., Serrano, D., Delgado, A., Tella, J.L., Bortolotti, G.R., 2013. Can synchronizing feather-based measures of corticosterone and stable isotopes help us better understand habitat-physiology relationships? Oecologia 173, 731-743.

Fairhurst, G.D., Bond, A.L., Hobson, K.A., Ronconi, R.A., 2015. Feather-based measures of stable isotopes and corticosterone reveal a relationship between trophic position and physiology in a pelagic seabird over a 153-year period. Ibis 157, 273-283.

Ferguson, A., Taggart, J.B., 1991. Genetic differentiation among the sympatric brown trout (Salmo trutta) populations of Lough Melvin, Ireland. Biol. J. Linn. Soc. 43, 221-237.

Flores, A.M., Shrimpton, J.M., Patterson, D.A., Hills, J.A., Cooke, S.J., Yada, T., Moriyama, S., Hinch, S.S., Farrell, A.P., 2012. Physiological and molecular endocrine changes in maturing wild sockeye salmon, Oncorhynchus nerka, during ocean and river migration. J. Comp. Physiol. B 182, 77-90.

France, R.L., 1995a. Carbon-13 enrichment in benthic compared to planktonic algae: foodweb implications. Mar. Ecol. Prog. Ser. 124, 307-312.

France, R.L., 1995b. Differentiation between littoral and pelagic food webs in lakes using stable carbon isotopes. Limnol. Oceanogr. 40, 1310-1313.

Gamperl, A.K., Vijayan, M.M., Boutilier, R.G., 1994. Experimental control of stress hormone levels in fishes: techniques and applications. Rev. Fish Biol. Fish. 4, 215-255.

Gilmour, K.M., 2005. Mineralocorticoid receptors and hormones: fishing for answers. Endocrinology 146, 44-46.

Glennemeier, K.A., Denver, R.J., 2002. Small changes in whole-body corticosterone content affect larval Rana pipiens fitness components. Gen. Comp. Endocrinol. 127, 16-25. 
Grey, J., 2001. Ontogeny and dietary specialization in brown trout (Salmo trutta L.) from Loch Ness, Scotland, examined using stable isotopes of carbon and nitrogen. Ecol. Freshw. Fish $10,168-176$.

Hansen, M.M., Ruzzante, D.E., Nielsen, E.E., Bekkevold, D., Mensberg, K.-L.D., 2002. Long-term effective population sizes, temporal stability of genetic composition and potential for local adaptation in anadromous brown trout (Salmo trutta) populations. Mol. Ecol. 11, 25232535.

Harris, G.S., 1971. The freshwater feeding of adult sea trout in the Afon Dyfi (midWales). Fish. Manage. 2, 20-23.

Harrison, X.A., Blount, J.D., Inger, R., Norris, D.R., Bearhop, S., 2011. Carry-over effects as drivers of fitness differences in animals. J. Anim. Ecol. 80, 4-18.

Hau, M., Casagrande, S., Ouyang, J.Q., Baugh, A.T., 2016. Glucocorticoid-mediated phenotypes in vertebrates: multilevel variation and evolution. Adv. Study Behav. 48, 1-75.

Hermes-Lima, M., Storey, K.B., 1996. Relationship between anovia exposure and antioxidant status in the frog Rana pipiens. Am. J. Physiol.: Regul. Integr. Comp. Physiol. 271, R918-R925.

Hobson, K.A., 1999. Tracing origins and migration of wildlife using stable isotopes: a review. Oecologia 20, 314-326.

Hobson, K.A., Piatt, J.F., Pitocchelli, J., 1994. Using stable isotopes to determine seabird trophic relationships. J. Anim. Ecol. 63, 786-798.

Hoogenboom, M.O., Metcalfe, N.B., Groothuis, T.G.G., de Vries, B., Costantini, D., 2012. Relationship between oxidative stress and circulating testosterone and cortisol in prespawning female brown trout. Comp. Biochem. Physiol. A 163, 379-387.

Hossie, T.J., Ferland-Raymond, B., Burness, G., Murray, D.L., 2010. Morphological and behavioural responses of frog tadpoles to perceived predation risk: a possible role for corticosterone mediation? Ecoscience 17, 100-108.

Hughes, M.R., Van Leeuwen, T.E., Cunningham, P.D., Adams, C.E., 2016. Parentally acquired differences in resource availability between brown trout from alternative life history parentage. Ecol. Fresh. Fish 2016, 1-8.

Hutchinson, J.J., Trueman, C.N., 2006. Stable isotope analyses of collagen in fish scales: limitations set by scale architecture. J. Fish Biol. 69, 1874-1880. 
Jensen, H., Kiljunen, M., Amundsen, P.-A. 2012. Dietary ontogeny and niche shift to piscivory in lacustrine brown trout Salmo trutta revealed by stomach content and stable isotope analyses. J. Fish Biol. 80, 2448-2462.

Jensen, H., Kahilainen, K.K., Vinni, M., Gjelland, K.O., Malinen, T., Harrod, C., Amundsen, P.-A., 2015. Food consumption rates of piscivorous brown trout (Salmo trutta) foraging on contrasting coregonid prey. Fish. Management Ecol. 22, 295-306.

Jensen, H., Kiljunen, M., Knudsen, R., Amundsen, P.-A., 2017. Resource partitioning in food, space and time between Arctic charr (Salvelinus alpinus), brown trout (Salmo trutta) and European whitefish (Coregonus lavaretus) at the southern edge of their continuous coexistence. PLoS ONE 12, e0170582.

Jonsson, B., 1985. Life history patterns of freshwater resident and sea-run migrant brown trout in Norway. Trans. Am. Fish. Soc. 114, 182-194.

Jonsson, B., 1989. Life history and habitat use of Norwegian brown trout (Salmo trutta). Fresh. Biol. 21, 71-86.

Jonsson, B., Gravem, F.R., 1985. Use of space and food by resident and migrant brown trout, Salmo trutta. Environ. Biol. Fishes 14, 281-293.

Jonsson, B., Jonsson, N., 2001. Polymorphism and speciation in Arctic charr. J. Fish Biol. 58, 605-638.

Karpestam, E., Forsman, A., 2011. Dietary differences among colour morphs of pygmy grasshoppers revealed by behavioural experiments and stable isotopes. Evol. Ecol. Res. 13, 461477.

Kelly, J.F., 2000. Stable isotopes of carbon and nitrogen in the study of avian and mammalian trophic ecology. Can. J. Zool. 78, 1-27.

Killen, S.S., Marras, S., Metcalfe, N.B., McKenzie, D.J., Domenici, P., 2013. Environmental stressors alter relationships between physiology and behaviour. Trends Ecol. Evol. 28, 651-658.

Klemetsen, A., Amundsen, P.-A., Dempson, J.B., Jonsson, B., Jonsson, N., O’Connell, M.F., Mortensen, E., 2003. Atlantic salmon Salmo salar L., brown trout Salmo trutta L. and Arctic charr Salvelinus alpinus (L.): a review of aspects of their life histories. Ecol. Freshw. Fish $12,1-59$. 
Klingenberg, C.P., 2016. Size, shape, and form: concepts of allometry in geometric morphometrics. Develop. Genes Evol. 226, 113-137.

Knutsen, J.A., Knutsen, H., Gjosaeter, J., Jonsson, B., 2001. Food of anadromous brown trout at sea. J. Fish Biol. 59, 533-543.

Knutsen, J.A., Knutsen, H., Olsen, E.M., Jonsson, B., 2004. Marine feeding of anadromous Salmo trutta during winter. J. Fish Biol. 64, 89-99.

Lesser, M.P., 2006. Oxidative stress in marine environments: biochemistry and physiological ecology. Ann. Rev. Physiol. 68, 253-278.

Martin, R.A. Pfennig, D.W., 2010. Field and experimental evidence that competition and ecological opportunity promote resource polymorphism. Biol. J. Linn. Soc. 100, 73-88.

McCarthy, I.D., Waldron, S., 2000. Identifying migratory Salmo trutta using carbon and nitrogen stable isotope ratios. Rapid Comm. Mass Spectrom. 14, 1325-1331.

McCarthy, I.D., Fraser, D., Waldron, S., Adams, C.E., 2004. A stable isotope analysis of trophic polymorphism among Arctic charr from Loch Ericht, Scotland. J. Fish Biol. 65, 14351440.

McCormick, S.D., 2001. Endocrine control of osmoregulation in teleost fish. Am. Zool. 41, 781-794.

McCormick, S.D., Bradshaw, D., 2006. Hormonal control of salt and water balance in vertebrates. Gen. Comp. Endocrin. 147, 3-8.

McGraw, K.J., Cohen, A.A., Costantini, D., Horak, P., 2010. The ecological significance of antioxidants and oxidative stress: a marriage between mechanistic and functional perspectives. Funct. Ecol. 24, 947-949.

McVeigh, H.P., Hynes, R.A., Ferguson, A., 1995. Mitochondrial DNA differentiation of sympatric populations of brown trout, Salmo trutta L., from Lough Melvin, Ireland. Can. J. Fish. Aquat. Sci. 52, 1617-1622.

Metcalfe, N.B., Alonso-Alvarez, C., 2010. Oxidative stress as a life-history constraint: the role of reactive oxygen species in shaping phenotypes from conception to death. Funct. Ecol. 24, 984-996.

Monet, G., Uyanik, A., Champigneulle, A., 2006. Geometric morphometrics reveals sexual and genotypic dimorphisms in the brown trout. Aquat. Living Resour. 19, 47-57. 
O’Connor, C.M., Norris, D.R., Crossin, G.T., Cooke, S.J., 2014. Biological carryover effects: linking common concepts and mechanisms in ecology and evolution. Ecosphere 5, 1-11.

Olofsson, H., Mosegaard, H., 1999. Larger eggs in resident brown trout living in sympatry with anadromous brown trout. Ecol. Fresh. Fish 8, 59-64.

Olsson, I. C., Greenberg, L.A., 2004. Partial migration in a landlocked brown trout population. J. Fish Biol. 65, 106-121.

Olsson, I.C., Greenberg, L.A., Bergman, E., Wysujack, K., 2006. Environmentally induced migration: the importance of food. Ecol. Lett. 9, 645-651.

Paez, D.J., Brisson-Bonenfant, C., Rossignol, O., Guderley, H.E., Bernatchez, L., Dodson, J.J., 2011. Alternative developmental pathways and the propensity to migrate: a case study in the Atlantic salmon. J. Evol. Biol. 24, 245-255.

Pankhurst, N.S., 2011. The endocrinology of stress in fish: an environmental perspective. Gen. Comp. Endocrin. 170, 265-275.

Peiman, K.S., Robinson, B.W., 2017. Comparative analyses of phenotypic trait covariation within and among populations. Am. Nat. 190, doi: \#\#\#\#.

Peters, L.D., Porte, C., Albaiges, J., Livingstone, D.R., 1994. 7-ethoxyresorufin $O$ deethylase (EROD) and antioxidant enzyme activities in larvae of sardine (Sardina pilchardus) from the north coast of Spain. Mar. Pollut. Bull. 28, 299-304.

Pettersson, J.C.E., Hansen, M.M., Bohlin, T., 2001. Does dispersal from landlocked trout explain the coexistence of resident and migratory trout females in a small stream? J. Fish Biol. $58,487-495$.

Pisoschi, A.M., Pop, A., 2015. The role of antioxidants in the chemistry of oxidative stress: a review. European J. Med. Chem. 97, 55-74.

Polis, G.A., 1984. Age structure component of niche width and intraspecific resource partitioning: can age groups function as ecological species? Am. Nat. 123, 541-564.

Pottinger, T.G., Rand-Weaver, M., Sumpter, J.P., 2003. Overwinter fasting and refeeding in rainbow trout: plasma growth hormone and cortisol levels in relation to energy mobilization. Comp. Biochem. Physiol. B 136, 403-417.

Reale, D., Garant, D., Humphries, M.M., Bergeron, P., Careau, V., Montiglio, P.-O., 2010. Personality and the emergence of the pace-of-life syndrome concept at the population level. Phil. Trans. R. Soc. B 365, 4051-4063. 
Ricklefs, R.E., Wikelski, M., 2002. The physiology/life-history nexus. Trends Ecol. Evol. 17, 462-468.

Rikardsen, A.H., Amundsen, P.-A., 2005. Pelagic marine feeding of Arctic charr and sea trout. J. Fish Biol. 66, 1163-1166.

Rikardsen, A.H., Amundsen, P.-A., Sandring, S., 2006. Seasonal marine feeding and body condition of sea trout (Salmo trutta) at its northern distribution. ICES J. Mar. Sci. 63, 466475.

Ringler, N.H., 1985. Individual and temporal variation in prey switching by brown trout, Salmo trutta. Copeia 1985, 918-926.

Robinson, B.W., Wilson, D.S., 1994. Character release and displacement in fishes: a neglected literature. Am. Nat. 144, 596-627.

Rohlf, F.J., 2015. The tps series of software. Hystrix 26, 9-12.

Roughgarden, J., 1972. Evolution of niche width. Am. Nat. 106, 683-718.

Rubenstein, D.R., Hobson, K.A., 2004. From birds to butterflies: animal movement patterns and stable isotopes. Trends Ecol. Evol. 19, 256-263.

Sanchez-Hernandez, J., Servia, M.J., Vieira-Lanero, R., Cobo, F, 2012. Ontogenetic dietary shifts in a predatory freshwater fish species: the brown trout as an example of a dynamic fish species. In: Turker, H. (Ed.), New Advances and Contributions to Fish Biology. InTech, doi:10.5772/54133.

Selman, C., Blount, J.D., Nussey, D.H., Speakman, J.R. 2013. Oxidative damage, ageing, and life-history evolution: where now? Trends Ecol. Evol. 27, 570-577.

Shirvell, C.S., Dungey, R.G., 1983. Microhabitats chosen by brown trout for feeding and spawning in rivers. Trans. Am. Fish. Soc. 112, 355-367.

Skoglung, S., Siwertsoon, A., Amundsen, P.-A., Knudsen, R., 2015. Morphological divergence between three Arctic charr morphs - the significance of the deep-water environment. Ecol. Evol. 5, 3114-3129.

Skúlason, K., Smith, T.B., 1995. Resource polymorphisms in vertebrates. Trends Ecol. Evol. 10, 366-370.

Smith, T.B., 1990. Resource use by bill morphs of an African finch: evidence for intraspecific competition. Ecol. 71, 1246-1257. 
Smith, T.B., Skúlason, S., 1996. Evolutionary significance of resource polymorphisms in fishes, amphibians, and birds. Ann. Rev. Ecol. Syst. 27, 111-133.

Speakman, J.R., Blount, J.D., Bronikowski, A.M., Buffenstein, R., Isaksson, C., Kirkwood, T.B.L., Monaghan, P., Ozanne, S.E., Beaulieu, M., Briga, M., Carr, S.K., Christensen, L.L., Cocheme, H.M., Cram, D.L., Dantzer, B., Harper, J.M., Jurk, D., King, A., Noguera, J.C., Salin, K., Sild, E., Simons, M.J.P., Smith, S., Stier, A., Tobler, M., VItikainen, E., Peaker, M., Selman, C., 2015. Oxidative stress and life histories: unresolved issues and current needs. Ecol. Evol. 24, 5745-5757.

Streans, S.C., 1989. Trade-offs in life-history evolution. Funct. Ecol. 3, 259-268.

Sumpter, J.P., Le Bail, P.Y., Pickering, A.D., Pottinger, T.G., Carragher, J.F., 1991. The effect of starvation on growth and plasma growth hormone concentrations of rainbow trout, Oncorhynchus mykiss. Gen. Comp. Endocrin. 83, 94-102.

Svanback, R., Bolnick, D.I., 2007. Intraspecific competition drives increased resource use diversity within a natural population. Proc. R. Soc. B 274, 839-844.

Svanback, R., Persson, L., 2004. Individual diet specialization, niche width and population dynamics: implications for trophic polymorphisms. J. Anim. Ecol. 73, 973-982.

Van Leeuwen, T.E., Killen, S.S., Metcalfe, N.B., Adams, C.E., 2016. Differences in early developmental rate and yolk conversion efficiency in offspring of trout with alternative life histories. Ecol. Freshw. Fish 26, 371-382.

Van Valen, L., 1965. Morphological variation and width of ecological niche. Am. Nat. 99, 377-389.

Vitousek, M.N., Tomasek, O., Albrecht, T., Wilkins, M.R., Safran, R.J., 2016. Signal traits and oxidative stress: a comparative study across populations with divergent signals. Front. Ecol. Evol. 4, 56.

Vuori, K., Kiljunen, M., Kanerva, M., Koljonen, M.-.L., Nikinmaa, M., 2012. Stockspecific variation of trophic position, diet and environmental stress markers in Atlantic salmon Salmo salar during feeding migrations in the Baltic Sea. J. Fish Biol. 81, 1815-1833.

Warne, R.W., Proudfoot, G.A., Crespi, E.J., 2015. Biomarkers of animal health: integrating nutritional ecology, endocrine ecophysiology, ecoimmunology, and geospatial ecology. Ecol. Evol. 5, 557-566. 
Wilson, D.S., 1998. Adaptive individual differences within single populations. Phil. Trans. R. Soc. Lond. B 353, 199-205.

Wilson, S.M., Gravel, M., Mackie, T.A., Willmore, W.G., Cooke, S.J., 2012. Oxidative stress associated with paternal care in smallmouth bass (Micropterus dolomieu). Comp. Biochem. Physiol. A 162, 212-218.

Wysujack, K., Greenberg, L.A., Bergman, E., Olsson, I.C., 2009. The role of the environment in partial migration: food availability affects the adoption of a migratory tactic in brown trout Salmo trutta. Ecol. Freshw. Fish 18, 52-59.

Zera, A.J., Harshman, L.G., 2001. The physiology of life history trade-offs in animals. Annu. Rev. Ecol. Syst. 32, 95-126. 


\section{Figure legends}

Fig. 1. Map of the study system.

Fig. 2. Representative image of a brown trout (Salmo trutta) digitized for meristic measures, the unbending procedure and geometric morphometrics. (A) Sea-run trout. (B) Stream-resident trout. Fig. 3. Multivariate and partial correlations for (A) male resident; (B) female resident; (C) male sea-run; and (D) female sea-run brown trout (Salmo trutta). Note that partial correlations were not calculated for female residents. Bold lines and bold font indicate significant multivariate correlations; dashed lines and normal font indicate significant partial correlations $(p<0.05)$. Correlation coefficients are given for both. $* p<0.05, * * p<0.01, * * * p<0.001$

Fig. 4. The relationship between head morphology (PC1) and nitrogen stable isotope values $\left(\delta^{15} \mathrm{~N}\right)$ of male stream-resident brown trout (Salmo trutta). Deformation grids (exaggerated x 3 for clarity) for extreme positive and negative PC scores are shown.

Fig. 5. The relationship between stress-induced cortisol levels and (A) head morphology (PC1) in female sea-run trout; (B) head morphology (PC1) in female resident trout; C) body morphology (PC2) in male sea-run trout. Deformation grids (exaggerated x3 for clarity) for extreme positive and negative PC scores are shown. Note differences in scale along Y-axis.

Fig. 6. The relationship between carbon stable isotope values $\left(\delta^{13} \mathrm{C}\right)$ and stress-induced cortisol concentrations. The relationship was significant in males (stream-resident: closed circles with corresponding solid line; sea-run: closed triangles with corresponding solid line) but not in females (stream-resident: open circles with corresponding dashed line; sea-run: open triangles with corresponding dashed line).

Fig. 7. The relationship between oxidative stress and carbon stable isotope $\left(\delta^{13} \mathrm{C}\right)$ values in male sea-run brown trout (Salmo trutta). Removal of the most extreme oxidative stress value (a potential outlier) did not change the significance of correlation $(p=0.0008)$ nor the partial correlation structure among variables. 


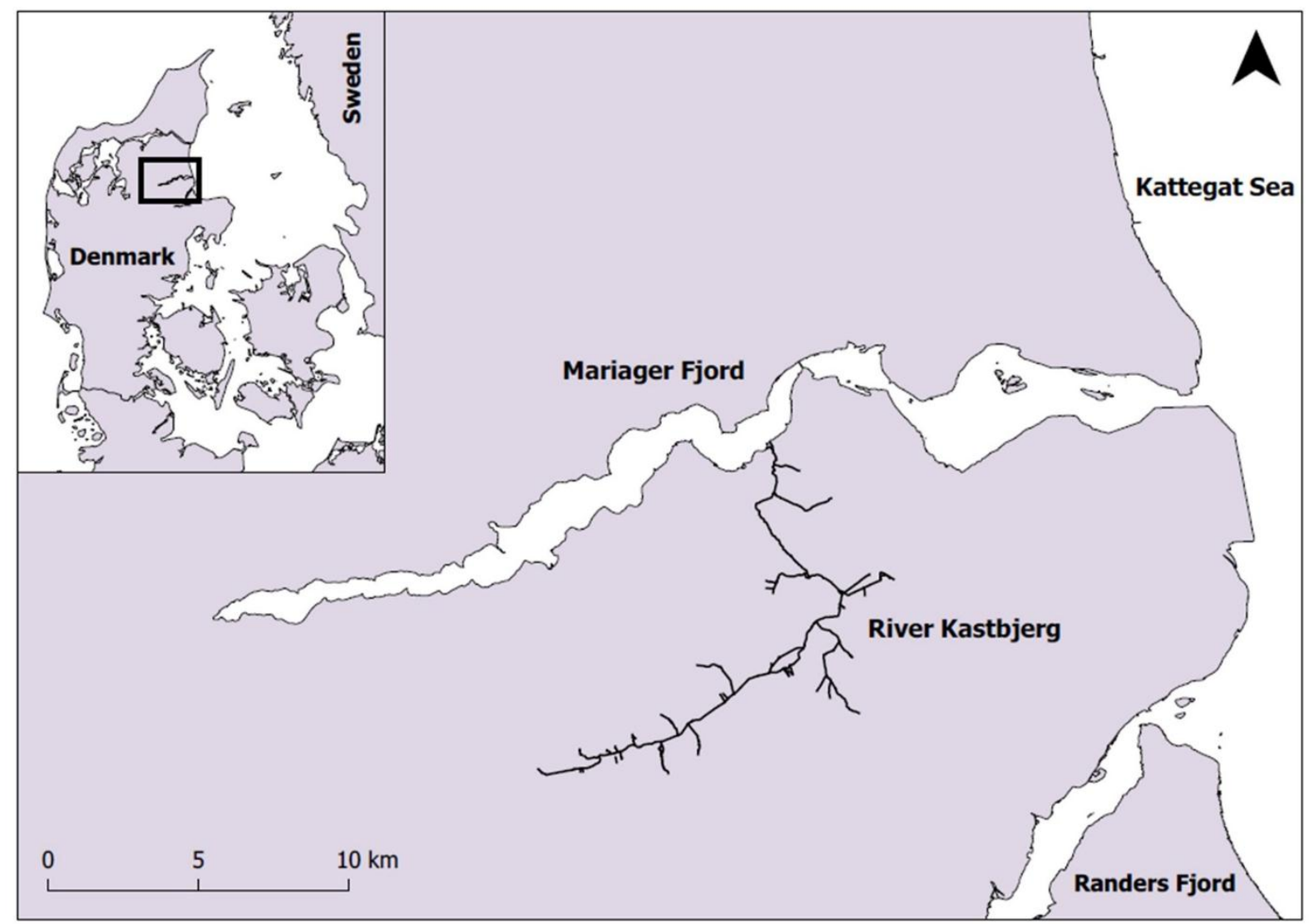

Figure 1 


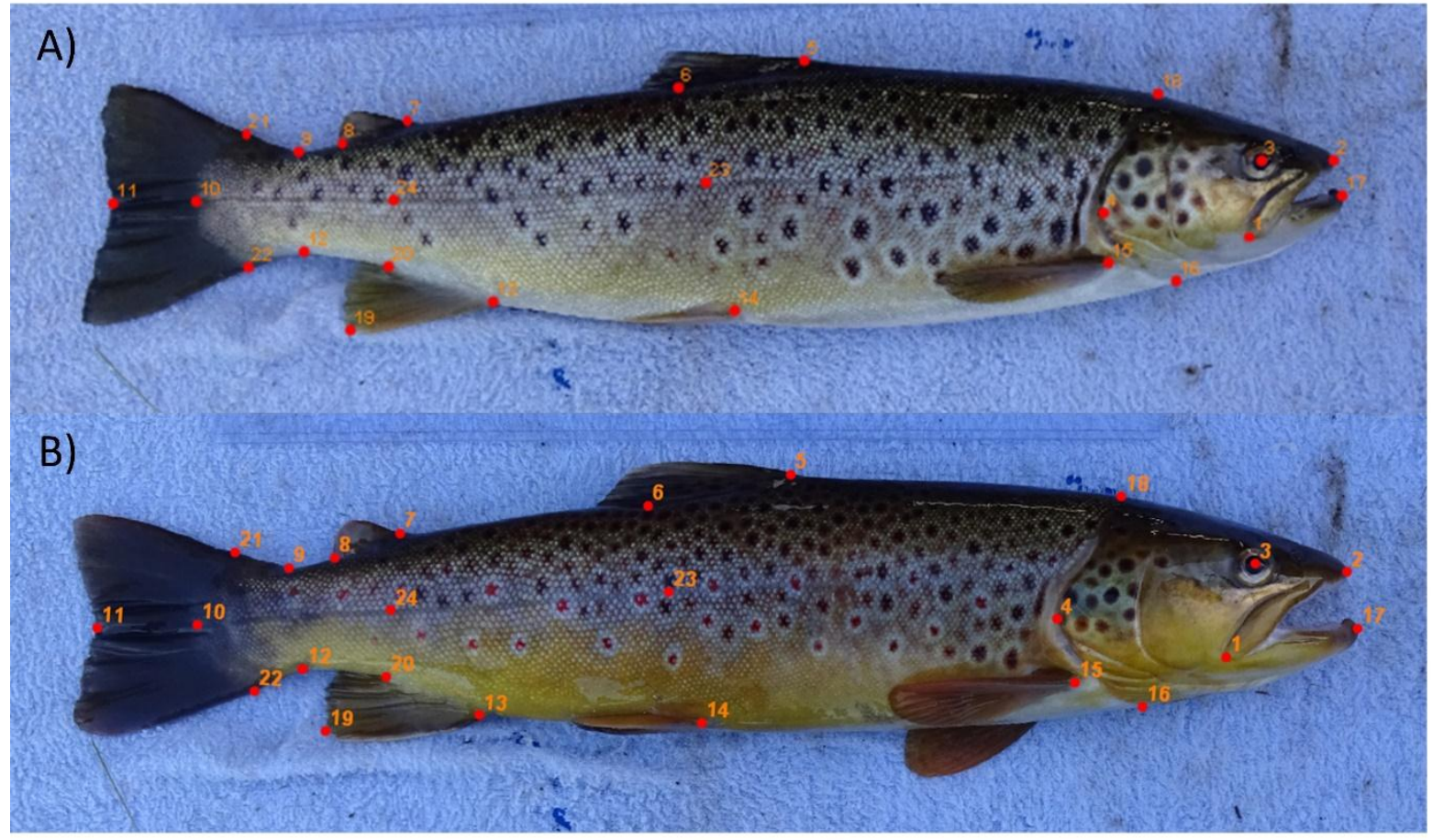

Figure 2

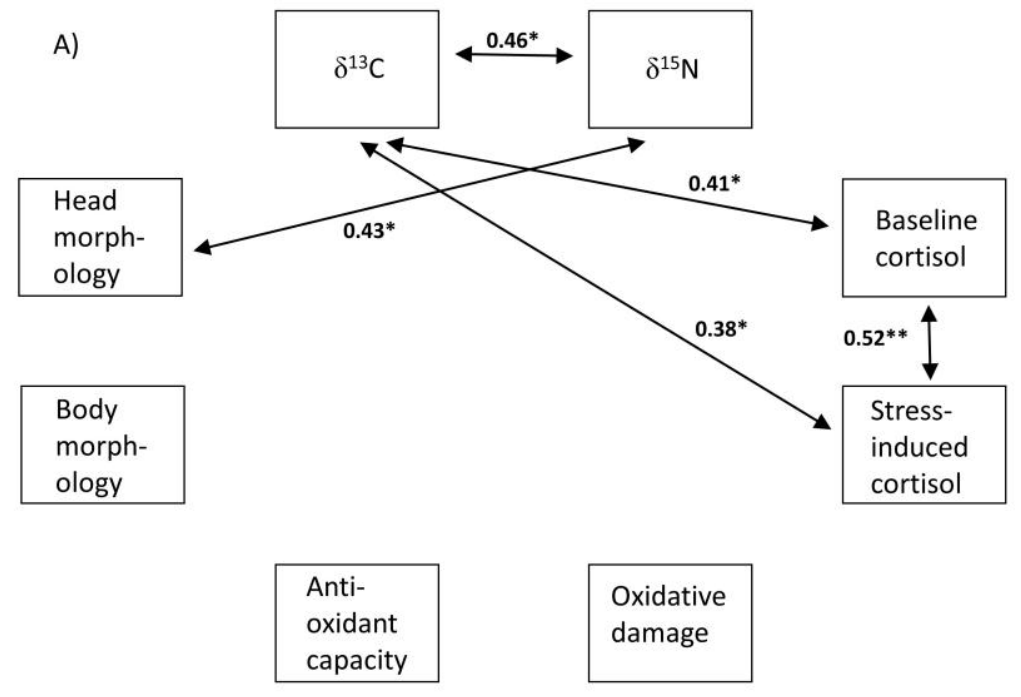


B)
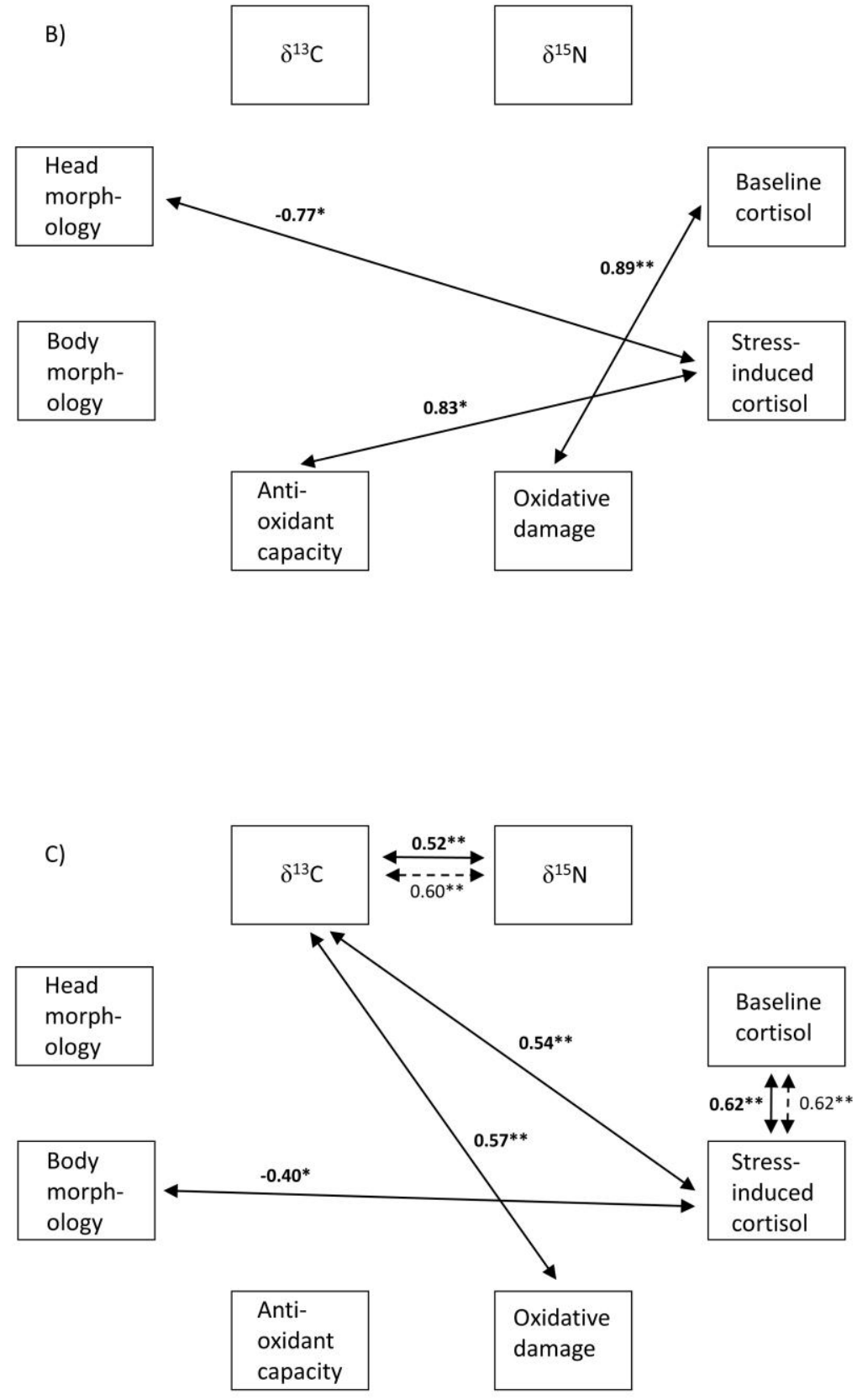


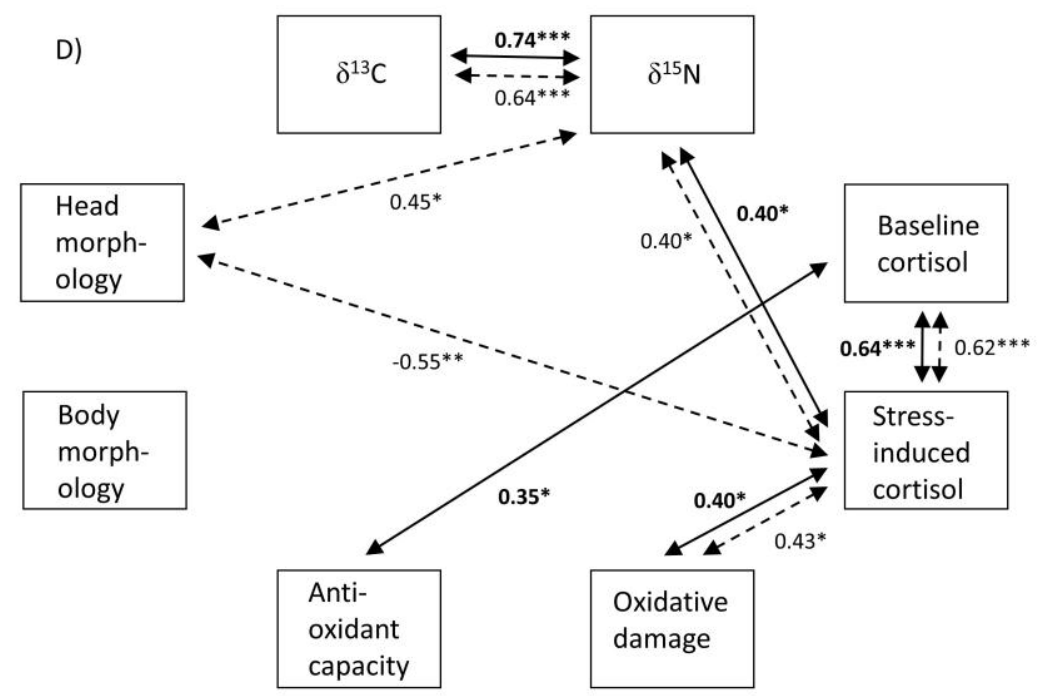

Figure no 3 


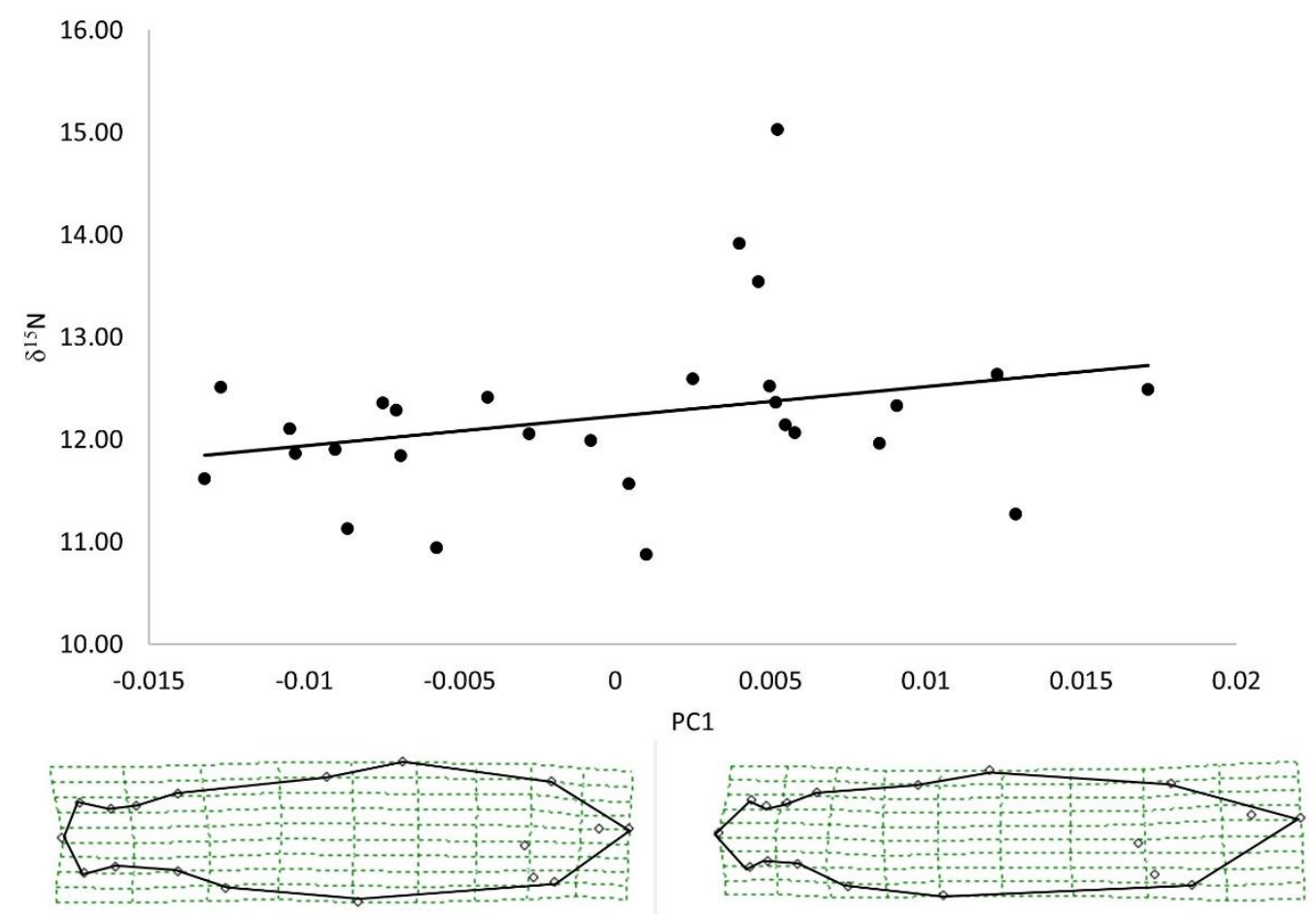

Figure 4 


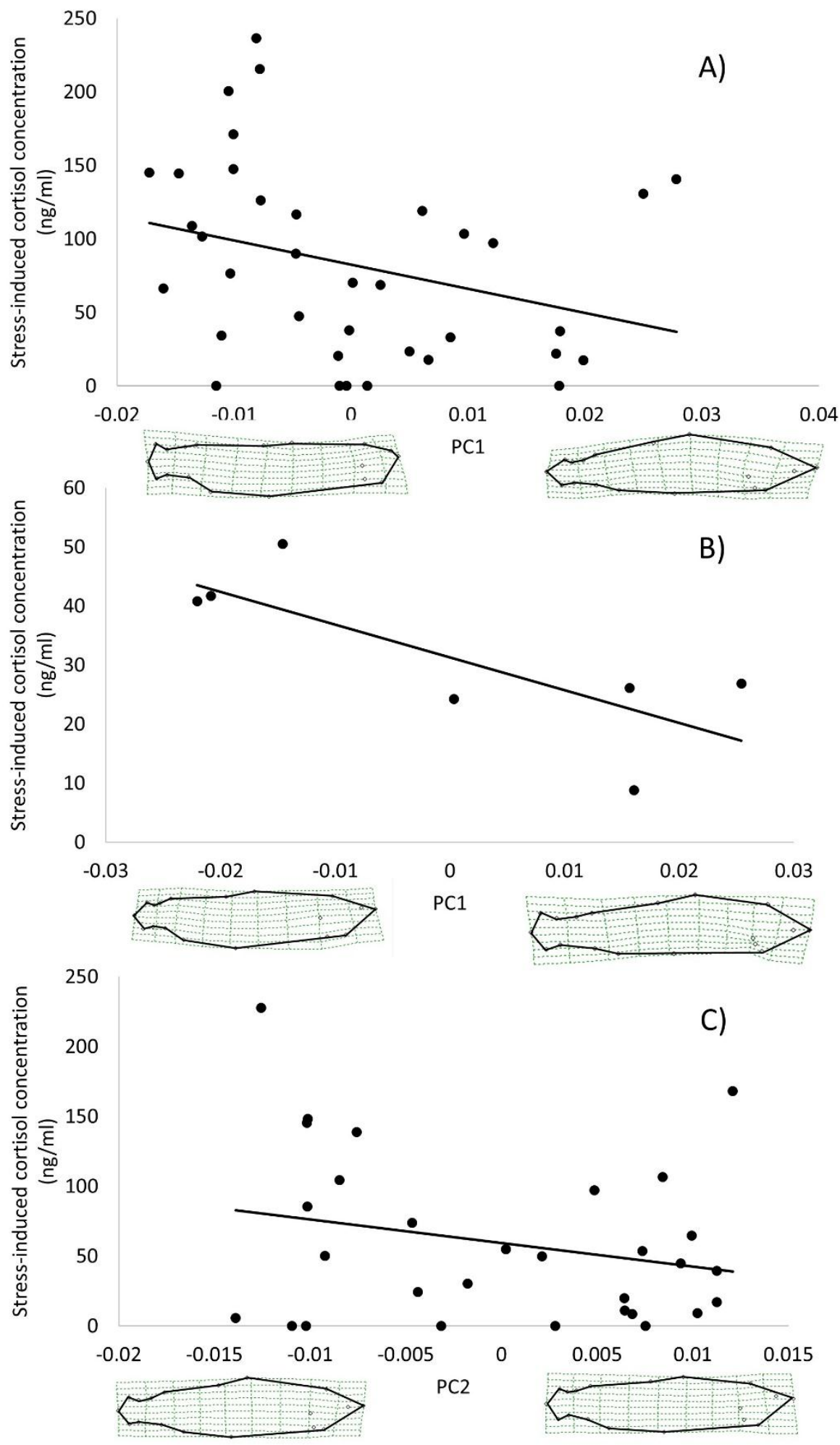

Figure 5 


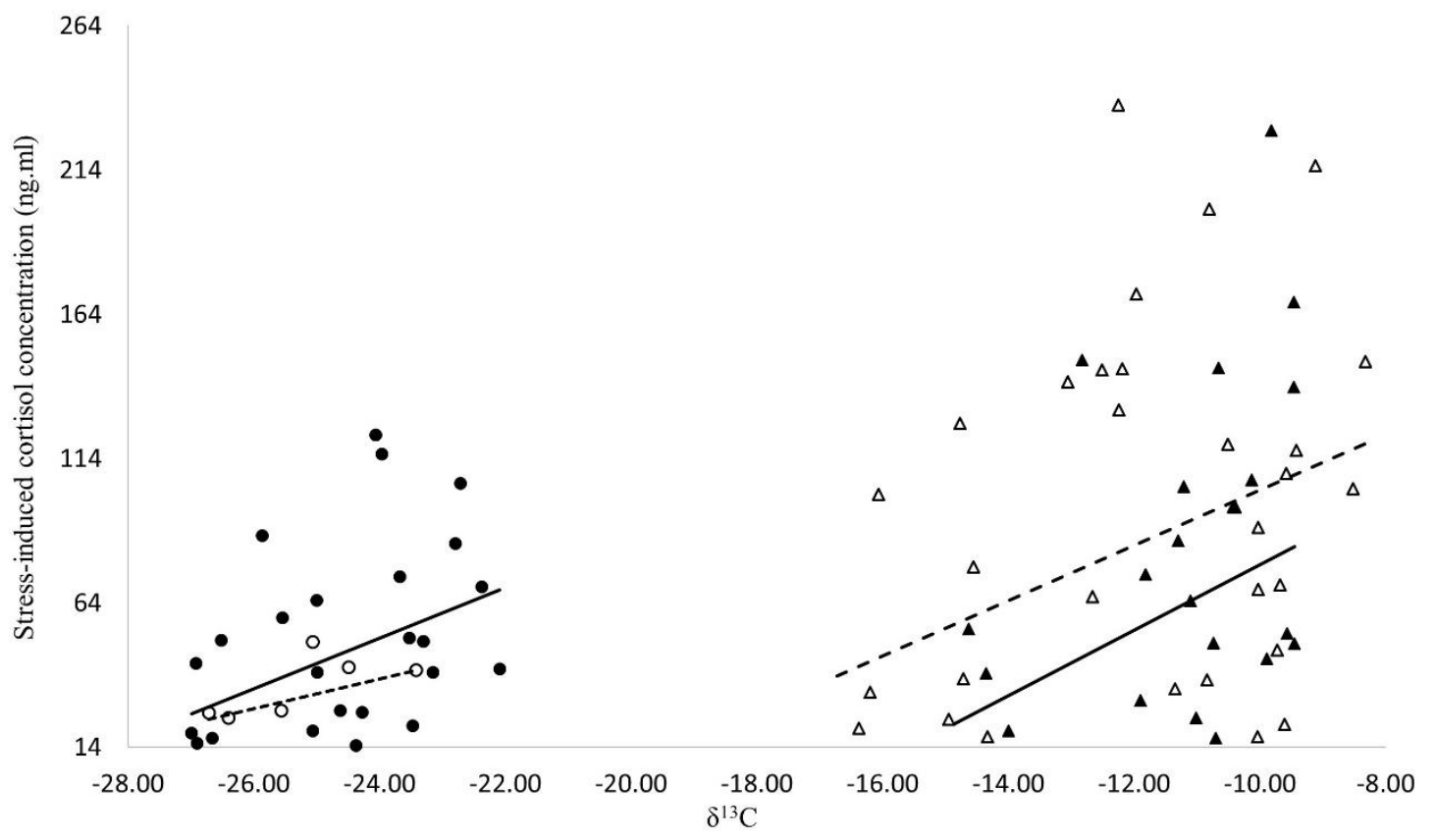

Figure 6 


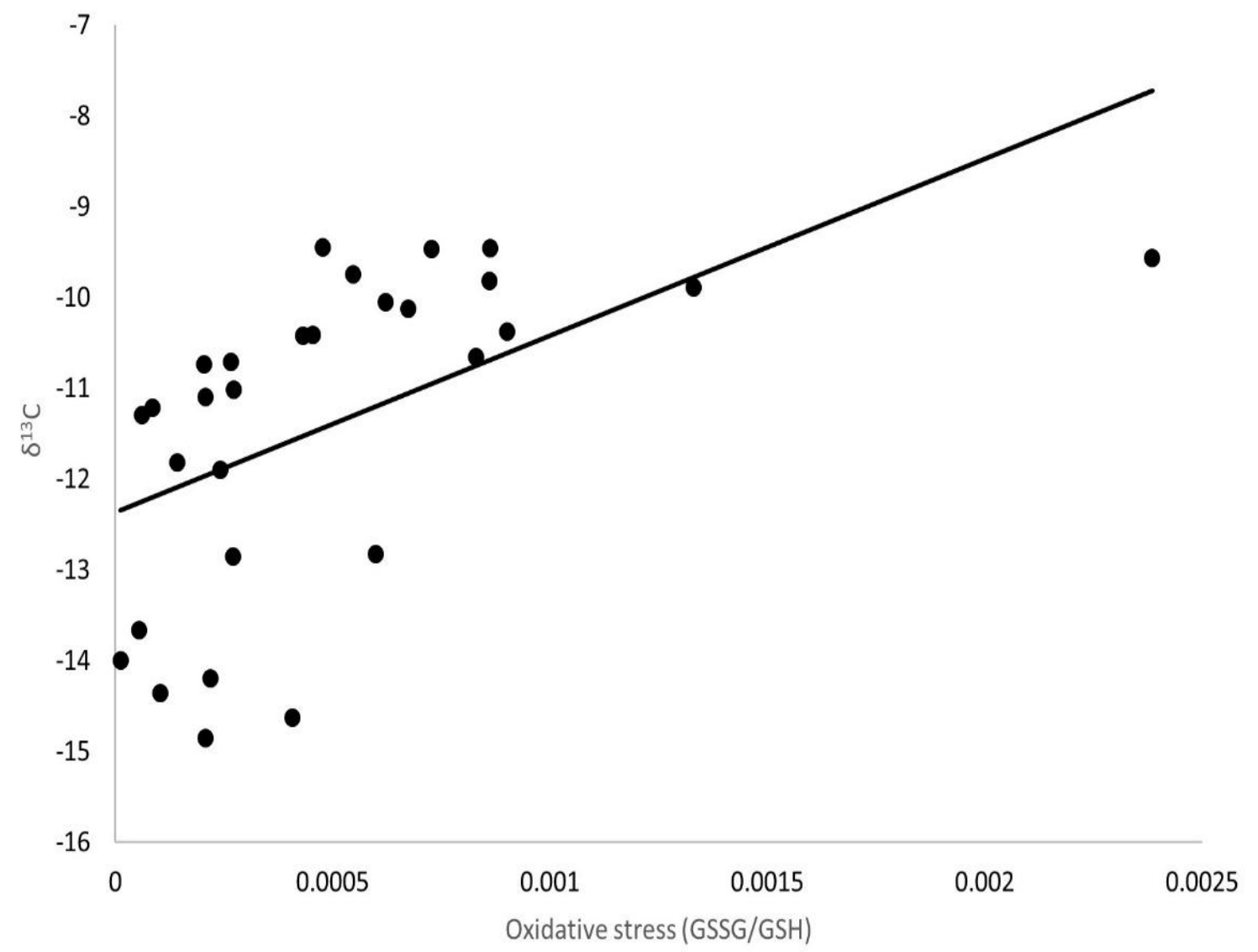

Figure 7 
Table 1. Summary statistics for male and female sea-run and stream-resident brown trout (Salmo trutta) sampled during breeding.

\begin{tabular}{|c|c|c|c|c|c|}
\hline & & Female & Male & Female & Male \\
\hline & & Resident & Resident & Sea-run & Sea-run \\
\hline \multirow[t]{3}{*}{ GSSG/GSH } & Mean \pm SE & $0.00019 \pm 0.00004$ & $0.00022 \pm 0.00005$ & $0.00035 \pm 0.00004$ & $0.00053 \pm 0.00009$ \\
\hline & Min, Max & $(0.000013,0.00036)$ & $(0,0.00097)$ & $(0,0.0011)$ & $(0.000012,0.0024)$ \\
\hline & $\mathrm{N}$ & 7 & 27 & 35 & 31 \\
\hline \multirow[t]{3}{*}{$\mathrm{TE}$} & Mean \pm SE & $15.3 \pm 1.0$ & $16.1 \pm 0.8$ & $17.0 \pm 1.0$ & $14.5 \pm 0.6$ \\
\hline & Min, Max & $(11.1,17.6)$ & $(10.4,27.0)$ & $(10.2,39.1)$ & $(6.5,22.2)$ \\
\hline & $\mathrm{N}$ & 7 & 27 & 35 & 31 \\
\hline \multirow[t]{3}{*}{$\delta^{13} \mathrm{C}$} & Mean \pm SE & $-25.2 \pm 0.4$ & $-24.7 \pm 0.3$ & $-12.2 \pm 0.4$ & $-11.4 \pm 0.3$ \\
\hline & Min, Max & $(-26.7,-23.4)$ & $(-27.0,-22.4)$ & $(-16.7,-8.3)$ & $(-14.9,-9.5)$ \\
\hline & $\mathrm{N}$ & 7 & 27 & 36 & 29 \\
\hline
\end{tabular}




\begin{tabular}{|c|c|c|c|c|c|}
\hline \multirow[t]{3}{*}{$\delta^{15} \mathrm{~N}$} & Mean $\pm \mathrm{SE}$ & $12.1 \pm 0.2$ & $12.1 \pm 0.1$ & $17.0 \pm 0.3$ & $17.6 \pm 0.2$ \\
\hline & Min, Max & $(11.3,12.9)$ & $(10.9,13.9)$ & $(12.7,20.1)$ & $(15.1,19.4)$ \\
\hline & $\mathrm{N}$ & 7 & 27 & 36 & 29 \\
\hline \multirow{3}{*}{$\begin{array}{l}\text { Baseline cortisol } \\
\text { concentration }\left(\mathrm{ng} \mathrm{ml}^{-1}\right)\end{array}$} & Mean $\pm \mathrm{SE}$ & $1.6 \pm 0.7$ & $2.2 \pm 0.9$ & $9.3 \pm 2.5$ & $8.2 \pm 2.6$ \\
\hline & Min, Max & $(0.4,4.9)$ & $(0.3,17.3)$ & $(0.4,66.4)$ & $(0.3,50.9)$ \\
\hline & $\mathrm{N}$ & 7 & 26 & 33 & 26 \\
\hline \multirow{3}{*}{$\begin{array}{l}\text { Stress-induced cortisol } \\
\text { concentration }\left(\mathrm{ng} \mathrm{ml}^{-1}\right)\end{array}$} & Mean $\pm \mathrm{SE}$ & $31.3 \pm 5.3$ & $46.6 \pm 6.5$ & $95.76 \pm 11.0$ & $71.1 \pm 11.7$ \\
\hline & Min, Max & $(8.8,50.5)$ & $(9.8,122.1)$ & $(17.5,236.4)$ & $(5.6,227.6)$ \\
\hline & $\mathrm{N}$ & 7 & 27 & 31 & 25 \\
\hline \multirow[t]{3}{*}{ Mass (g) } & Mean $\pm \mathrm{SE}$ & $247.6 \pm 77.1$ & $169.9 \pm 10.4$ & $917.8 \pm 70.0$ & $608.6 \pm 81.4$ \\
\hline & Min, Max & $(89,628)$ & $(77,301)$ & $(159,2523)$ & $(163,2196)$ \\
\hline & $\mathrm{N}$ & 7 & 28 & 36 & 30 \\
\hline \multirow[t]{2}{*}{ Length $(\mathrm{cm})$} & Mean $\pm \mathrm{SE}$ & $27.3 \pm 2.7$ & $24.7 \pm 0.5$ & $43.5 \pm 1.2$ & $36.5 \pm 1.7$ \\
\hline & Min, Max & $(20.6,39.3)$ & $(18.7,30.8)$ & $(23.2,62.3)$ & $(23.0,57.5)$ \\
\hline
\end{tabular}


Table 2. Eigenvalues and percent variance explained by the first two principal components of geometric morphology for male and female stream-resident and sea-run brown trout (Salmo trutta).

$\begin{array}{lllll} & \text { PC1 } & \text { PC1 } & \text { PC2 } & \text { PC2 } \\ & \text { Eigenvalue } & \text { \% Variance } & \text { Eigenvalue } & \text { \% Variance } \\ & & & & \\ \text { Stream-resident female } & 0.00038 & 57.37 & 0.000114 & 17.259 \\ \text { Stream-resident male } & 0.000115 & 25.613 & 0.0000668 & 14.84 \\ \text { Sea-run female } & & & & \\ \text { Sea-run male } & 0.000149 & 28.796 & 0.0000691 & 13.382 \\ & & & & \\ & 0.0000955 & 22.732 & 0.0000595 & 13.298\end{array}$

